Portland State University

PDXScholar

Summer 8-7-2019

\title{
Parr Going the Distance: How Migratory Difficulty Influences Red Muscle Lipid Storage in Juvenile Oncorhynchus mykiss
}

Emily Jean Morse

Portland State University

Follow this and additional works at: https://pdxscholar.library.pdx.edu/open_access_etds

Part of the Biology Commons

Let us know how access to this document benefits you.

\section{Recommended Citation}

Morse, Emily Jean, "Parr Going the Distance: How Migratory Difficulty Influences Red Muscle Lipid Storage in Juvenile Oncorhynchus mykiss" (2019). Dissertations and Theses. Paper 5173.

https://doi.org/10.15760/etd.7049

This Thesis is brought to you for free and open access. It has been accepted for inclusion in Dissertations and Theses by an authorized administrator of PDXScholar. Please contact us if we can make this document more accessible: pdxscholar@pdx.edu. 
Parr Going the Distance: How Migratory Difficulty Influences Red Muscle Lipid Storage in Juvenile Oncorhynchus mykiss.

\section{by}

\section{Emily Jean Morse}

A thesis submitted in partial fulfillment of the requirements for the degree of

\section{Master of Science}

in Biology

Thesis Committee:

Kim H. Brown, Chair

Angela Strecker

Bradley Buckley

Portland State University 2019 
(C) Emily Jean Morse 


\section{ABSTRACT}

Adult salmonid populations embarking on difficult migrations have evolved to store more somatic energy prior to river entry. While it is known that lipids are the primary fuel for endurance swimming in fish, uncertainty still surrounds how these mechanisms are utilized by juvenile fish during seaward migration. A key phase in salmonid migration is the preparatory season of feeding and growth before swimming downstream. During this period, juvenile fish build somatic fuel stores through dietary uptake. Intestinal microbiota of steelhead trout (Oncorhynchus mykiss) vary drastically across their geographic range, with significant differences in the coastal and inland subspecies' microbiota lipid metabolism, suggesting variation for host lipid absorption. Along the O. mykiss range there is a vast difference in migration difficulty experienced by individual populations. In order to investigate the relationship between migration difficulty and lipid storage in premigration juvenile steelhead in the Columbia River Basin, lateralis muscle (red, type I) lipid storage was assessed across hatchery stocks. Lipid storage was quantified using fluorescent microscopy and image analysis with FIJI (ImageJ). To date, no published studies have quantified fish lipid storage with these techniques. Inland juveniles' lipid stores increased significantly with migration difficulty and number of anticipated dam passages. While the coastal subspecies stocks had no significant change in lipid storage associated with migration difficulty, individuals had significantly higher lipid stores than inland fish and lower mean body condition. Taken together, there is evidence that smoltification timing may be an equally important factor in parr lipid storage. Results from this study characterize juvenile lipid storage pre-migration, and elicit new questions about 
how smoltification rates may be impacted by migratory transit time to marine feeding grounds. 


\section{ACKNOWLEDGEMENTS}

Truly, I would like to give my sincere gratitude to my advisor, Dr. Kim H. Brown, for guiding this project and encouraging me along the way, for your support, and for always helping me find the right direction in a sea of information. Not only have you helped me succeed here at Portland State, but your confidence in me has helped further my next academic adventure at Washington State University.

I would also like to thank my thesis committee members, Dr. Brad Buckley and Dr. Angela Strecker, for being active participants in my time as a graduate student. You have both helped expand my understanding of physiology, of fish and their value, and most importantly- thank you for challenging me to stand up for my ideas.

This research was made possible with funding from the Kim Brown Lab, the Portland State University Forbes Lea Endowment for Student Research, and the LernerGray Fund for Marine Research through the American Museum of Natural History. Additionally, I could not have completed my thesis without surplus fish provided by Oregon Department of Fish and Wildlife Hatcheries, Washington Department of Fish and Wildlife Hatcheries, or the Washington State University Center for Reproductive Biology Aquaculture Core.

My time at here was made incalculably richer by the friends I have made along the way. Thank you to my lab mates, Lindsay Holden and Decatur Foster, you have both been such a pleasure to work with and learn from. I appreciate you taking me under your wings, I am more confident and a better scientist for it. Lindsay, you were instrumental in my initial design of this project, and such an inspiration as a researcher. Decatur, your friendship has been a source of joy and support, thank you for your excellent editing 
skills, and all of the haircuts in the lab. Another colleague who has been a source of friendship and of research community includes Amy Suefert, thank you for getting excited over little victories with me, and your willingness to help with edits.

The Lutterschmidt lab has been instrumental in making this research happen. Thank you to Dr. Deborah Lutterschmidt for trusting me with your cryostat over the last several months. I would also like to thank and acknowledge Kalera Stratton, Rachel Wilson, and Treven Winters for teaching me many of the techniques I utilized in this project, and for your camaraderie through it all.

Finally, I could not have done this without the support of my family. Jori, you have been my biggest source of support and encouragement through the last two years. I would not have started this journey without you inspiring me to reach higher, and together we're making our dreams happen. Thank you for showing me how strong I can be, and for listening to me talk endlessly about fish. Thank you to all of my parents and my grandparents for fostering my early interest in animals and science, you helped spark my interest in the natural world. Anyone who knows me will recognize this is a core part of who I am today.

Thank you. 


\section{TABLE OF CONTENTS}

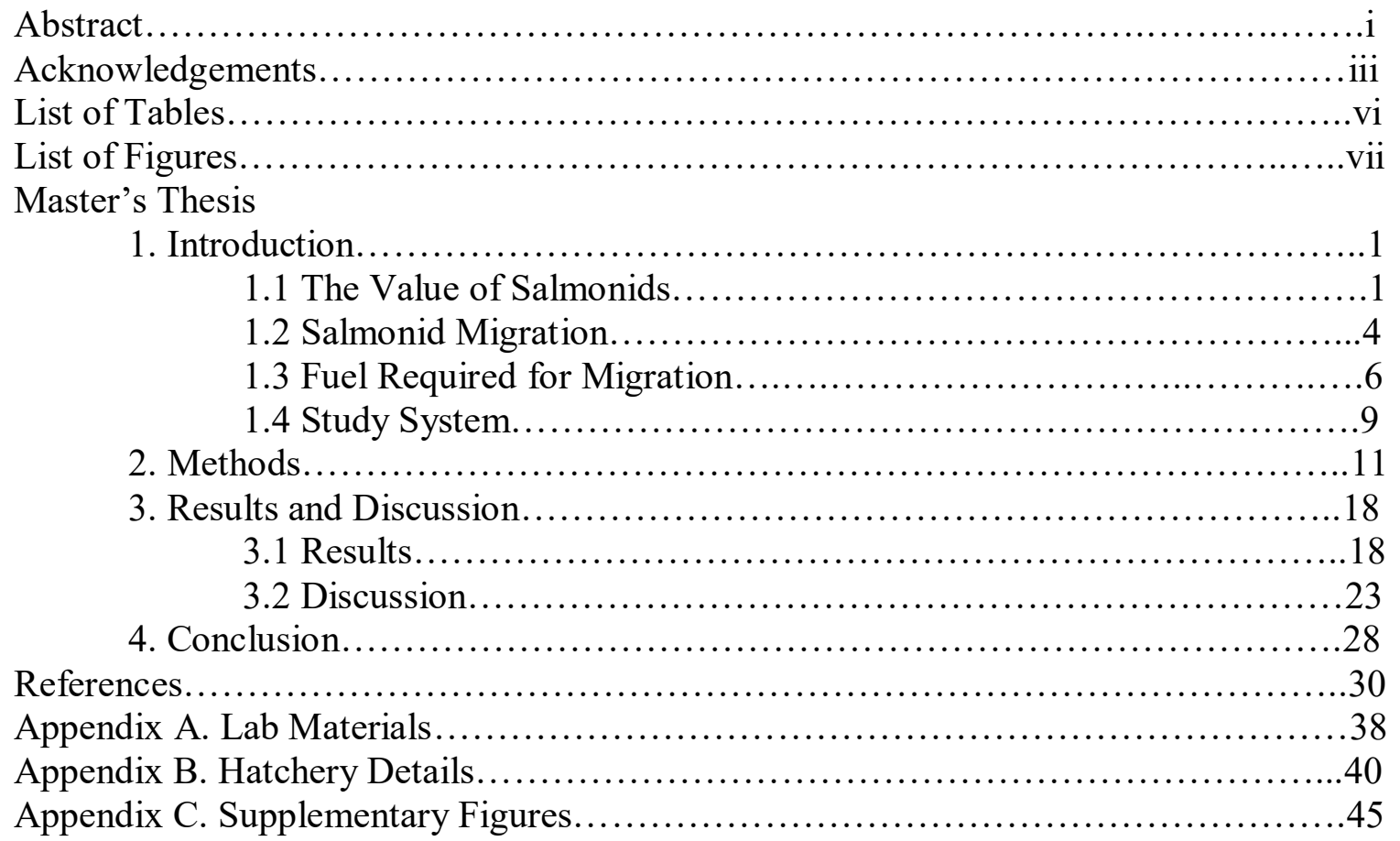




\section{LIST OF TABLES}

Table 1. Summary of staining protocol of teleost red muscle (type I fibers) with oil red O for fluorescent image analysis. Page 14.

Table 2. Biological characteristics of pre-release juvenile steelhead summarized by subspecies and hatchery stock, means are reported \pm standard deviation $(n=140)$. Page 18.

Table 3. Summary of Fit and ANOVA for actual juvenile red muscle Log(LAI) versus modeled values $(n=29)$. Page 23 . 


\section{LIST OF FIGURES}

Figure 1. Evolutionary timeline of Oncorhynchus genus and phylogeny of north Pacific salmonids (Augerot and Foley, 2005). Page 1.

Figure 2. Phylogeographic range of steelhead in Washington, Oregon, and Idaho. Orange designates $O$. mykiss gairdneri populations, yellow and hatched areas designate $O$. mykiss irideus populations, and rivers in red constitute steelhead trout ESA critical habitat. Scale bar is $100 \mathrm{~km}$ (NOAA Office of Response \& Restoration, 2019). Page 6.

Figure 3. Selected coastal O. mykiss irideus (blue) and inland O. mykiss gairdneri (red) stocks used in this study from the Columbia River and tributaries (upper) and Kenai Peninsula (lower). Page 10.

Figure 4. A juvenile steelhead trout (O. mykiss irideus) with body wall removed as described and red muscle (left) and white muscle (right) biopsies shown. Page 12.

Figure 5. Orientation of red muscle within cryomold. Page 13.

Figure 6. Fluorescent microscopy of $O$. mykiss red muscle tissue stained with oil red $\mathrm{O}$, 40x with 1.5 optical zoom. Page 15.

Figure 7. Red muscle lipid storage in juvenile hatchery steelhead pre-release by subspecies. Shaded areas refer to $95 \% \mathrm{CI}(\mathrm{DF}=50, \mathrm{p}=0.0020)$. Coastal $\mathrm{n}=38$, inland $\mathrm{n}$ $=29$. Page 20 .

Figure 8. Red muscle lipid storage in juvenile hatchery steelhead pre-release by migratory difficulty (work) from either the coastal or inland subspecies. Shaded areas refer to $95 \%$ CI (coastal $n=38$, inland $n=29$ ). Page 21 .

Figure 9. Measured red muscle lipid storage in inland juvenile steelhead pre-release by migratory difficulty (work) in red, and predicted values from a model equation including number of dam passages per stock in purple. Number of dams encountered by each stock from left to right are Umatilla (3), Deschutes (2), and Imnaha (8). Model equation: $\log (\mathrm{LAI})=0.0010969$ (work) -0.047166 (dams) -1.017718 . Shaded areas refer to $95 \%$ CI (inland $=29$ ). Page 22.

Figure 10. Comparison of juvenile O. mykiss lipid storage in red muscle by stock and subspecies (S. Santiam $n=8$, Umatilla $n=9$ ). Shaded area refers to a 95\% CI. Page 24 . 


\section{INTRODUCTION}

\subsection{THE VALUE OF SALMONIDS}

Almost one-half of all vertebrate species on Earth belong to one of the four classes of fish: Cephalaspidomorphi (lampreys), Myxini (hagfish), Chondrichthyes (cartilaginous fishes), and the superclass Osteichthyes (bony fish, or teleosts). Among teleosts, the majority belong to the subclass Actinopterygii (ray-finned fishes), which encompass most extant fish species (Stevens and Hume, 1998). This immense group includes one of the most iconic fish families of the Pacific Northwest, Salmonidae, to which the charismatic salmon and trout of the genus Oncorhynchus belong (Figure 1).

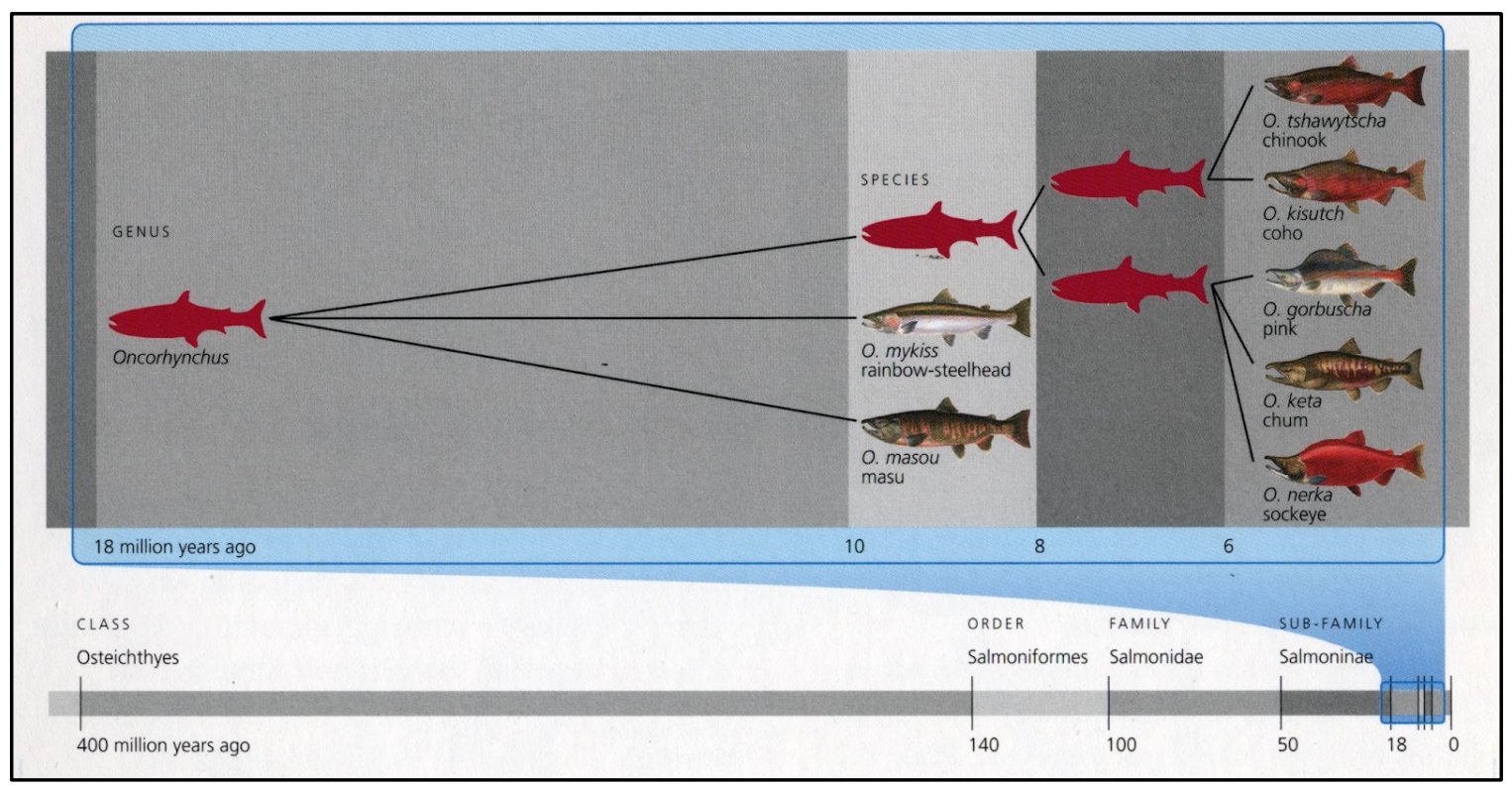

Figure 1. Evolutionary timeline of Oncorhynchus genus and phylogeny of north Pacific salmonids (Augerot and Foley, 2005).

The current marine distribution of Oncorhynchus spans the northern Pacific Ocean with freshwater spawning grounds perforating the western coast of the Russian 
Kamchatka Peninsula, along the Gulf of Alaska, and down the western coast of the United States to southern California (Augerot and Foley, 2005). This genus has also been widely distributed artificially through aquaculture and recreational stocking. Since the 1930s, the number of fish stocked by United States government agencies has grown exponentially. In 2004 over 30 million pounds of Oncorhynchus spp. were spawned and released with more than half of these being Oncorhynchus mykiss, i.e. steelhead or rainbow trout (Halverson, 2010).

Even with an expansive natural range and increasing human cultivation through aquaculture, commercial landings of salmon and steelhead have been steadily decreasing since the early 1900s (Mann et al., 2005). Indiscriminate capture in ocean waters, also known as the problem of "mixed stock fishing", poses a disproportionate threat to smaller wild numbers of salmonids (Naish et al., 2007). Today, the majority of west coast salmonids are listed as Threatened or Endangered under the Endangered Species Act (ESA), and yet they still accounted for more than one thousand metric tons of Pacific fish brought in by ocean commercial fishing vessels in 2015 (NOAA Fisheries, 2017).

Fish hatcheries were established largely in response to this decline in fish population, societal demands, and legal obligation (Busby et al., 1986, Naiman et al., 2012, Kendall et al., 2017). Overharvest, anthropogenic habitat destruction, poor ocean conditions, and river impoundment have historically been the major threats to salmonids (McClure et al., 2003, Naish et al., 2007). Federal programs commonly involve stocking, reintroduction, and supplementation to existing populations (Flagg et al., 2000, Nickelson et al., 2010). Supplementation is the most common strategy on the west coast, and culminates in the annual release of millions of artificially propagated fish in an attempt to 
sustain wild populations (Naish et al., 2007). The Columbia River Basin is lauded as one of the largest fish restoration programs in the United States, with an annual operating budget of approximately \$311 million (Naiman et al., 2012)

Currently, $70-80 \%$ of commercially caught trout and salmon in Pacific Northwest waters derive from hatchery stocks (Flagg et al., 2000). Fishing on a recreational level also provides an economic boost to the Columbia River Basin, where direct expenditures on fishing tackle, gasoline, and other supplies from anglers contribute an estimated $\$ 2$ billion to local economies annually (Mann et al., 2005). In addition, fish provided by inland hatcheries for legal harvest can be an accessible source of animal protein and income empowerment in areas where poverty and marginalization often intersect (Lynch et al., 2016).

Salmonids are important on more than a fiscal level- they are also essential to regional aquatic ecology health. Migratory (anadromous) fish such as Oncorhynchus play a key role in inland nutrient cycling (Helfield and Naiman, 2001, Moore, 2006). Anadromy is a valuable strategy in the Pacific Northwest where temperate seas offer richer feeding than inland freshwater ecosystems (Kendall et al., 2014). The seasonal influx of mature fish to river systems brings nutrients like phosphorus and nitrogen back to the migratory corridors as well as spawning grounds via salmonid mortality. And finally, for species with one reproductive period before dying (semelparous), parental carcasses fertilize the stream where their offspring will eventually hatch and develop (Quinn, 2005).

Furthermore, the social value of fish is often overlooked in conventional scientific discourse (Lynch et al., 2016). In fact, capture of returning fish has a long history in the 
Columbia River Basin beyond today's anglers and hatcheries. To native people living along the river, salmon have been a lifeblood for time immemorial, essential to their subsistence, culture, and spiritual practices. Today, fishing continues to be the preferred livelihood for many tribal members, as the annual return of trout and salmon is celebrated by the tribes to honor the "renewal and continuation of human and all other life" (Columbia River Inter-Tribal Fish Commission, 2019).

\subsection{SALMONID MIGRATION}

Aside from human and environmental threats faced by salmonids, their anadromous life history brings its own particular challenges. Anadromous fish are designated as such by their voyage seaward as juveniles and eventual return to natal river spawning sites at sexual maturity. Each generation hatches and develops in freshwater until reaching a critical threshold of growth and development, where the decision is made to embark downstream to the ocean or remain in freshwater (Dickhoff et al., 1997, Forseth et al., 1999, Kendall et al., 2014). Juvenile fish (parr) migrating to marine waters undergo a transitional phase called smoltification. Smoltification involves complex changes in biochemistry, physiology, morphology, and metabolism. The timing of this cascade of events is dictated by both the fish's developmental "clock", and environmental cues (Nichols et al., 2008). The second, and final, migration culminates in reproduction and death (semelparity) where only those who survive contribute to the next generation. Both migrations to and from the ocean are crucial chapters in the Oncorhynchus life history. 
For O. mykiss, there are two life history options, each associated with a fitness trade-off: either migrate to sea and enjoy superior feeding grounds for 1-3 years prior to sexual maturity (steelhead trout), or remain in freshwater as a resident (rainbow trout) and avoid the perilous and arduous journey to and from the ocean (Quinn, 2005, Kendall et al., 2014). The decision whether or not to go to sea in a given year is influenced by a complex suite of factors including energy balance, size, sex, genetic architecture, and seasonal conditions (Nichols et al., 2008, Kendall et al., 2014). Additionally, within Pacific Salmonidae, steelhead are doubly unique in that they can be iteroparous (i.e., surviving after spawning and undergoing multiple oceanic migrations) instead of merely semelparous (Keefer et al., 2009).

Two major subspecies of $O$. mykiss are widely recognized in North America: O. mykiss gairdneri and O. mykiss irideus (Figure 2). These subspecies are demarcated by spawning grounds on either side of the Cascade Range at the historical site of Celilo Falls (Busby et al., 1996). O. mykiss gairdneri (inland) and O. mykiss irideus (coastal) lineages diverged after a series of glaciation events in the late Pleistocene (Behnke, 2002, Waples et al., 2008). O. mykiss can be further divided into reproductively isolated allopatric populations identified by historical spawning grounds, and sympatric populations by timing of adult river entry (i.e. summer-run vs. winter-run) (Taylor, 1991, Van Doornik et al., 2015). Salmonids have a high level of fidelity to their natal spawning sites, which range from within a few kilometers of the ocean to several hundred (Scheer, 1939, Bams, 1976). Temporal and geographic separation of Oncorhynchus populations combined with a multitude of migratory destinations have exerted distinct selective pressures resulting in local variation in each population's genetics, fecundity, physiology, 
and behavior associated with migration (Leider et al., 1986, Fleming and Gross, 1990, Crossin et al., 2004, Bradford et al., 2009, Fraser et al., 2011).

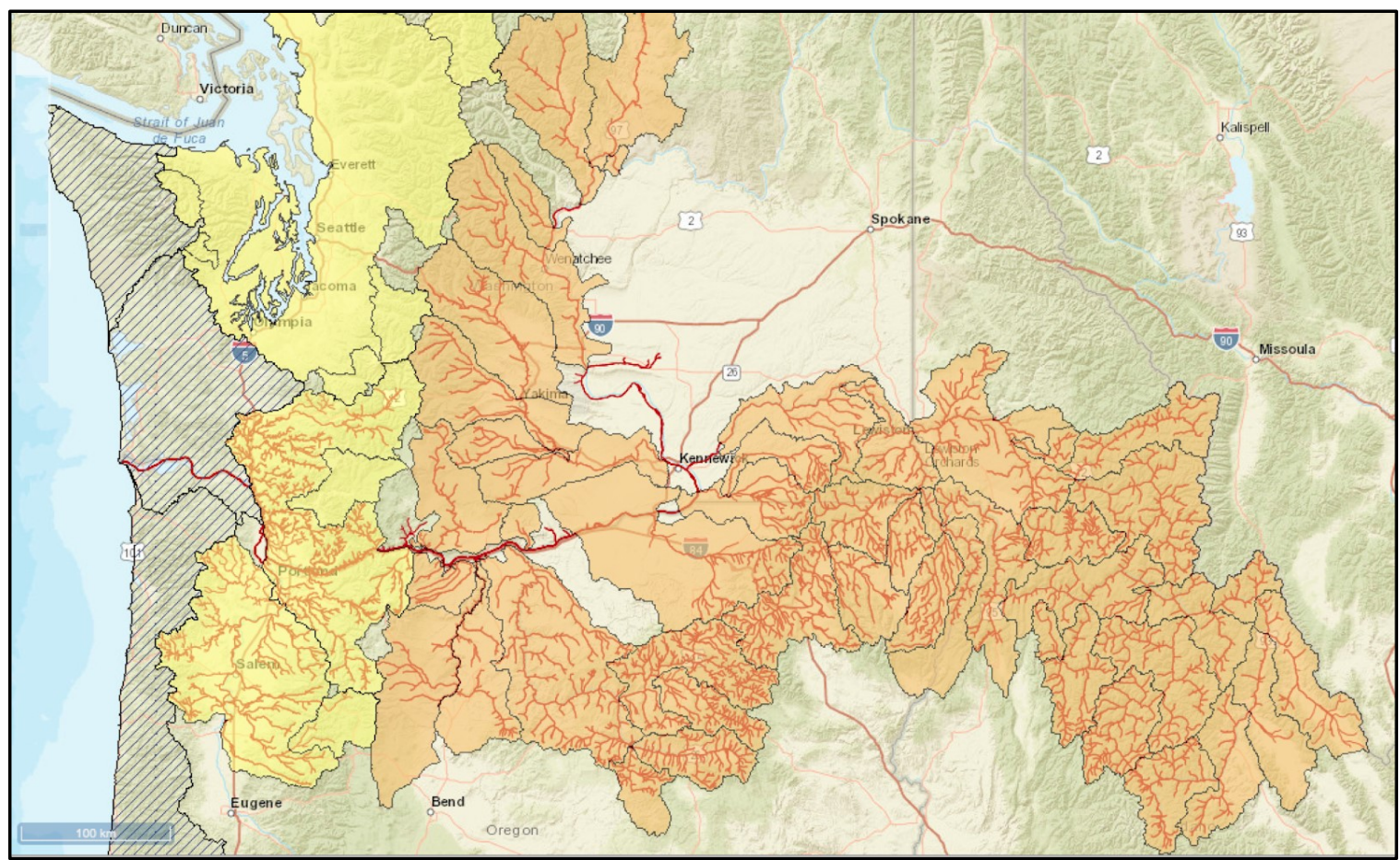

Figure 2. Phylogeographic range of steelhead in Washington, Oregon, and Idaho. Orange designates $O$. mykiss gairdneri populations, yellow and hatched areas designate O. mykiss irideus populations, and rivers in red constitute steelhead trout ESA critical habitat. Scale bar is $100 \mathrm{~km}$ (NOAA Office of Response \& Restoration, 2019).

\subsection{FUEL REQUIREMENTS FOR MIGRATION}

So then, what fuels the epic migrations of salmon? Lipids are a common energy source for many lifeforms, and the primary fuel for endurance swimming in fish (Kaneko et al., 2016, Magnoni and Weber, 2007). In fact, lipoprotein turnover rate in migrating trout surpasses all other endotherms studied to date (Weber, 2009). Somatic fuel storage is one such area in which salmonid populations are locally adapted, and amounts of stored lipid levels pre-migration increases with difficulty of the impending journey (Beckman et al., 2004, Crossin et al. 2004, Magnoni et al., 2006). In sockeye salmon ( $O$. 
nerka), individuals embarking on migrations with higher elevation and further distance have evolved more efficient energy allocation and expenditure in regards to total body lipid concentration (Crossin et al., 2004). Stored fuels are essential for determining migratory success, yet lipid storage has not been fully characterized in juvenile Oncorhynchus.

Even the downstream migration requires considerable physiological preparation. As justified by Quinn (2005), seaward "migration is not accomplished by passive displacement or drift, but by active, downstream swimming". In addition to traveling to marine waters, juvenile salmonids must budget energy for the physiological and morphological changes associated with the transition from a riverine environment to the open ocean. These dramatic changes associated with smoltification are also primarily fueled by prepared lipid deposits (Sheridan and Kao, 1998, Quinn 2005).

Fat can be held in droplets in skeletal muscles, rather than just in adipose tissue; these accumulations are known as lipid droplets (LDs), or more specifically, intramyocellular lipids (IMCLs). By storing fuel in close proximity to sarcoplasmic mitochondria, rapid oxidation can release energy to working muscles (SchrauwenHinderling et al., 2006, Benador et al., 2018). This strategy is preferentially used during prolonged submaximal exercise, rather than the multistep process of freeing and transporting triglyceride reserves from adipocytes (Schrauwen-Hinderling et al., 2006). Indeed, in vivo studies confirm both endurance swimming and smoltification strongly activate lipoprotein lipase (molecular lipid shuttles) in Oncorhynchus red muscle (Sheridan, 1989, Magnoni et al., 2006, Magnoni and Weber, 2007). 
A critical phase in salmonid migrations is the preparatory period of feeding and growth. For parr, this peaks just prior to initiation of migration (Beckman et al., 2004, Quinn, 2005). In anticipation of the energetically demanding period ahead, parr insulin and IGF-I levels spike in late winter stimulating somatic lipid and carbohydrate sequestration (Dickhoff et al., 1997, Quinn, 2005). Building somatic fuel stores requires considerable uptake and utilization of dietary lipids.

Recent research shows that intestinal microbiota of $O$. mykiss across the Columbia River Basin varies significantly between the coastal and inland populations, especially in pathways associated with host lipid absorption(Yildirimer and Brown, 2018). Vertebrates harbor diverse microbial communities in their intestinal tracts; these host-microbe relationships are known to be both complex and dynamic, affecting host development, physiology, immunity, and digestion (Cotillard et al., 2013, Montalban-Arques et al., 2015, Lowrey et al., 2015). Unsurprisingly, commensal microbial pathways are also essential in teleost nutrient absorption and lipid deposition and thus may play a critical role in juvenile trout pre-migration (Llewellyn et al., 2014). Additionally, fish and their intestinal microbiota have likely coevolved, and may follow patterns of local adaptation among populations (Lyons et al., 2017). Observed microbiome composition differences between coastal and inland populations may be an underlying factor in the known variation in Oncorhynchus fat storage by migration distance. 


\subsection{STUDY SYSTEM}

The guiding research goal of this study was to investigate the relationship between migration difficulty and lipid storage in pre-migration juvenile steelhead, and characterize any physiological differences between the coastal and inland subspecies. The focal measurement used was lipid accumulation in red muscle, due to its essential role in migration physiology. In order to spare threatened wild fish, and have a common rearing environment, hatchery fish propagated by Oregon Department of Fish and Wildlife (ODFW), Washington Department of Fish and Wildlife (WDFW), and clonal fish from the Washington State University Center for Reproductive Biology (CRB) were utilized in this study.

Hatchery O. mykiss are most commonly spawned, incubated, and reared in protected settings until they are released into rivers or lakes. Returning adults are then collected as broodstock for spawning upon reaching their hatchery of origin, thus contributing to the next generation of cultivated fish. Most commonly, supplementationfocused hatchery operations are conducted on the same river as the historical population they are propagating and released as "stocks". Stocks for this study were selected based on management proximity to the population's historical spawning grounds, run timing (all summer-run), and achieving an even distribution of sites along the Columbia River (Figure 3). While the hatchery environment can have documented effects on salmonids, utilizing non-threatened hatchery fish from a lineage of successful migrators was deemed well-founded for the purpose of this investigation (Flagg et al., 2000). 


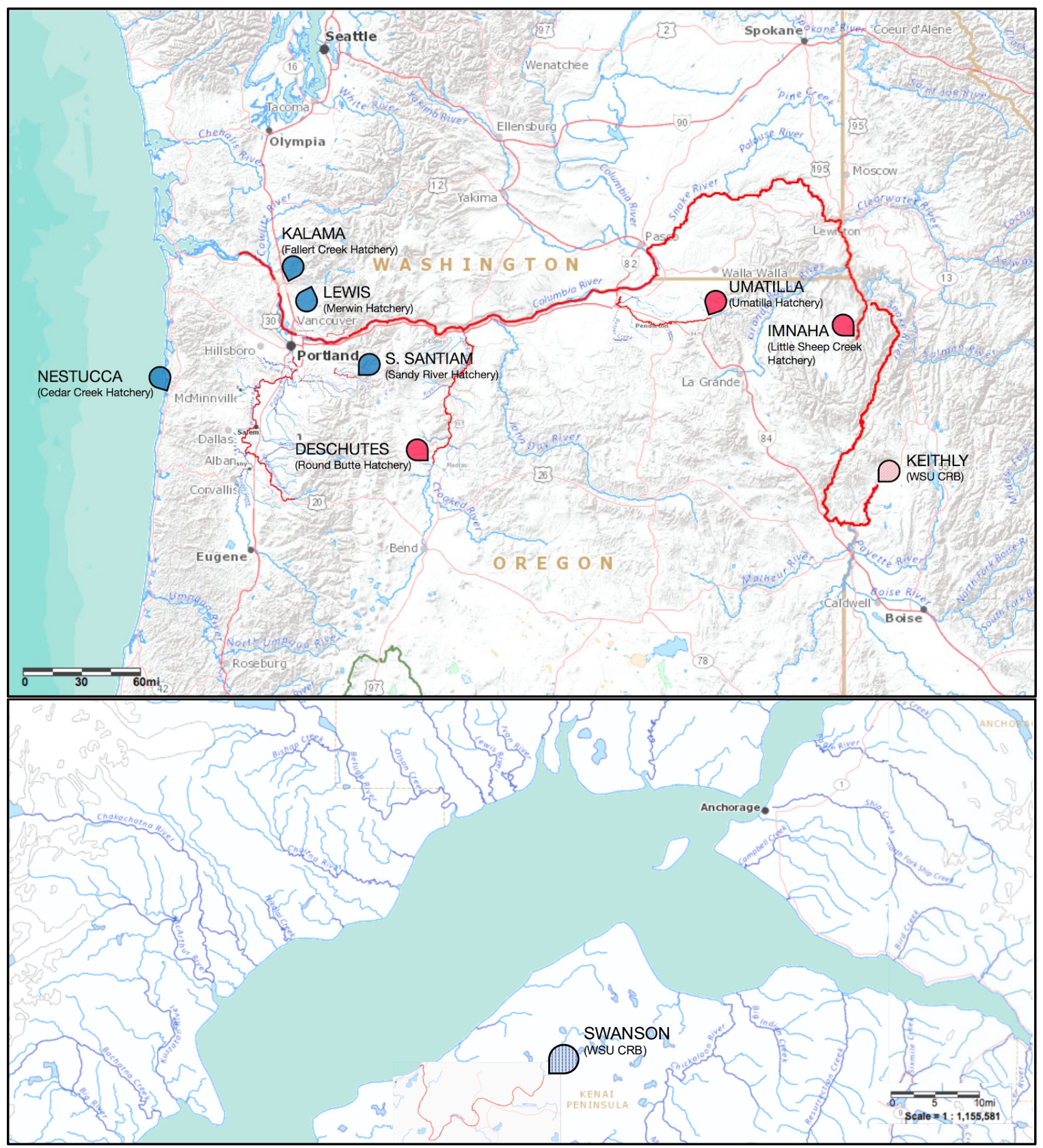

Figure 3. Selected coastal O. mykiss irideus (blue) and inland O. mykiss gairdneri (red) stocks used in this study from the Columbia River and tributaries (upper) and Kenai Peninsula (lower). 


\section{METHODS}

Hatcheries and propagated stock were selected based on history of program spawning fidelity (use of returning adults for broodstock), and to achieve an even representation of both subspecies with a diversity of migratory distances. Only summerrun steelhead stocks were collected for consistency, and for their larger geographic range in the Columbia River Basin (Behnke, 2002). Specific information about each hatchery can be found in Appendix A. Authorization to collect samples from hatchery surplus was provided by Oregon Department of Fish and Wildlife (ODFW) hatchery managers and from the Washington Department of Fish and Wildlife state office.

All parr were collected from the same brood-year and sampled no more than one week prior to release date. Twenty individual fish were randomly sampled from each hatchery by net capture. Collected specimens were immediately placed into a tank containing an overdose concentration (at least $0.1 \% \mathrm{w} / \mathrm{v}$ ) of the anesthetic MS-222 (Tricaine mesylate) mixed with clean hatchery water. Fish remained in the anesthetic overdose until opercular movement ceased, indicating death. To ensure death, all fish were given a sharp blow to the head as a secondary method to ensure humane death (Leary et al., 2013).

Fish weight was recorded to one tenth of a gram using a scale, and length was measured from snout to caudal peduncle to the nearest millimeter. Fish body condition was calculated by: $\mathrm{K}=10^{5} \mathrm{x}$ (weight $(\mathrm{g}) /$ length $^{3}(\mathrm{~mm})$ ) as described by Nichols et al. (2008). Each fish was then dissected by removing a rectangular panel of the body wall from the left lateral side, with margins centered below the dorsal fin, and extending to the 
ventral surface (Figure 4). The larger filet of muscle was then separated into smaller muscle biopsies, isolating the red and white muscle while leaving the skin intact for easy orientation. Fin clips were collected and immediately frozen for a DNA repository, and then stored at $-80^{\circ} \mathrm{C}$. Muscle biopsies were fixed in labeled caplets of $4 \%$ paraformaldehyde in phosphate buffer $[0.2 \mathrm{M}]$ for 24 hours at $4^{\circ} \mathrm{C}$ (Appendix A). After fixation, tissue pieces were rinsed and placed in a new labeled caplet of phosphate buffer $[0.1 \mathrm{M}]$ then returned to $4^{\circ} \mathrm{C}$. Fish sex was determined by visually examining the gonads.

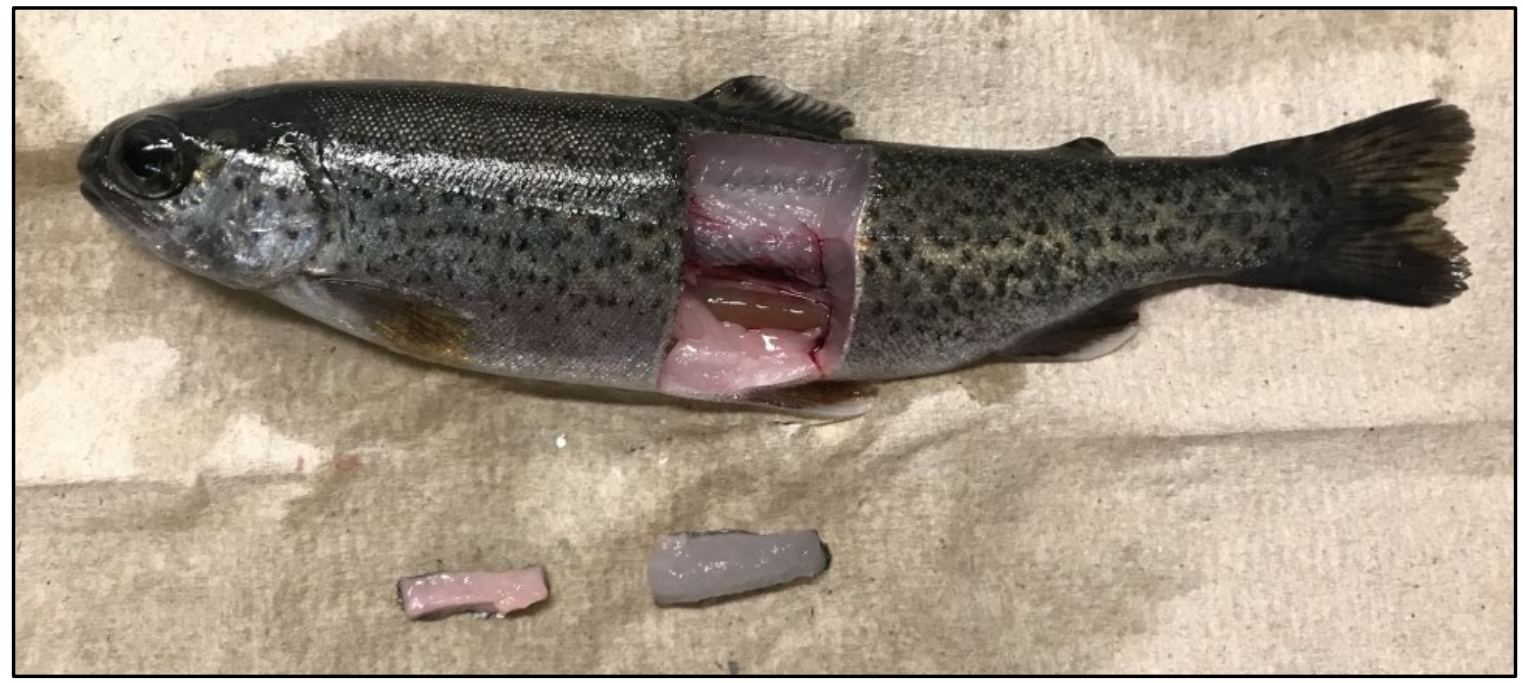

Figure 4. A juvenile steelhead trout (O. mykiss irideus) with body wall removed as described and red muscle (left) and white muscle (right) biopsies shown.

A random number generator was used to select 10 fish from each hatchery stock (with a 1:1 sex ratio) for sectioning and staining. All YY clonal males samples from the WSU CRB were sectioned and stained. For selected fish, a 3-4 mm transverse portion was removed from the muscle tissue sample for embedding and cryosectioning, with the remaining amount reserved in storage. To cryoprotect tissue subsamples from freezedamage, water was removed using a two-step sucrose method in PBS (Appendix A). 
Samples were fully submerged in the $10 \%$ sucrose solution first, followed by the $30 \%$ sucrose solution, ensuring all water had been safely removed from the tissue.

Prior to tissue embedding, a $-78.5^{\circ} \mathrm{C}$ isopentane (2-methylbutane) bath was prepared with crushed dry ice. The isopentane was allowed to equilibrate for $30-40$ minutes until sufficiently chilled. A metal bowl with a small suspended stage at the surface of the freezing isopentane was used to support molds. Tissue samples were individually removed from cryoprotectant, gently dried with a clean Kim-wipe (Kimberly Clark, Irving, TX), and allowed to acclimate for 5 minutes in an OCT bath containing Tissue-Tek ${ }^{\circledR}$ Optimal Cutting Temperature compound (Sakura Finetek, Torrance, CA). A thin layer of the embedding compound was used to coat the bottom well of labeled vinyl cryomolds $(25 \mathrm{~mm} \times 20 \mathrm{~mm}$ x $5 \mathrm{~mm})$ and frozen to provide a base for the tissue sample. Once the

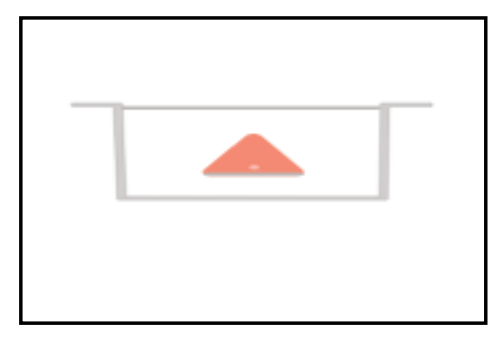

Figure 5. Orientation of red muscle within cryomold. base was frozen, the acclimated tissue sample was carefully arranged in the mold for transverse sections approximately 5-8 $\mathrm{mm}$ from the front, and completely surrounded with OCT (Figure 5). Molds were rapidly frozen and then wrapped in parafilm, followed by aluminum foil, labeled, and then kept on dry ice until storage at $-80^{\circ} \mathrm{C}$ in a sealed plastic bag.

Frozen muscle tissue samples were allowed to equilibrate to $-20^{\circ} \mathrm{C}$ for at least 30 minutes before sectioning with a 3050S cryostat (Leica Biosystems Inc., Buffalo Grove, IL). Sections were cut at $25 \mu \mathrm{m}$ thick and briefly thaw mounted on labeled positively charged glass slides (Appendix A). Five to six transverse sections were mounted on a 
single slide for each muscle sample. Slides were kept at $-20^{\circ} \mathrm{C}$ for no longer than one hour prior to staining.

Visualization of lipid droplets in muscle sections was accomplished using oil red $\mathrm{O}(\mathrm{ORO})$ in a triethylphosphate solution (Koopman et al., 2001). Oil red O is a fatsoluble diazo dye from the family of Sudan dyes which exhibits a high affinity for neutral triglycerides and lipids. ORO staining can be quantified with both brightfield and fluorescence microscopy (Koopman et al., 2001). To overcome crystallization, a common complaint with ORO solutions, a fresh working solution was mixed immediately prior to staining, and filtered using a wetted \#42 Whatman paper cone (Sigma-Aldrich, St. Louis, MO) as described by Koopman et al. (2001). Cryosectioning, staining, and imaging were always completed on the same day, minimizing temperature change and air drying to protect intramyocellular lipid droplets from shrinkage (Prats et al., 2013). A summary of the staining protocol used in this study is presented in Table 1. Modifying previous mammalian protocols to fit the unique morphology of teleost muscle tissue involved a process of careful optimization, as ORO fluorescent microscopy has not been utilized in fish. Tissue sections were mounted with a $10 \%$ glycerol solution in PBS, coverslipped and sealed with a clear butyl acetate polymer sealant (Koopman et al., 2001).

Table 1. Summary of staining protocol of teleost red muscle (type I fibers) with oil red O for fluorescent image analysis.

\begin{tabular}{lllllll}
\hline Protocol & $\begin{array}{l}\text { Thaw } \\
\text { slides }\end{array}$ & $\begin{array}{l}\text { Gently } \\
\text { submerge } \\
\text { in DI water }\end{array}$ & $\begin{array}{l}\text { Stain with } \\
\text { ORO } \\
\text { working } \\
\text { solution }\end{array}$ & $\begin{array}{l}\text { Gently } \\
\text { submerge } \\
\text { in DI water }\end{array}$ & $\begin{array}{l}\text { DI water } \\
\text { incubation } \\
\text { x2 }\end{array}$ & $\begin{array}{l}\text { Dry in } \\
\text { fume } \\
\text { hood }\end{array}$ \\
\hline $\begin{array}{l}\text { Length } \\
\text { of Time }\end{array}$ & $\begin{array}{l}\leq 5 \\
\text { minutes }\end{array}$ & $5-10 x$ & 10 minutes & $5-10 x$ & 5 minutes & $\begin{array}{l}12 \\
\text { minutes }\end{array}$ \\
\hline
\end{tabular}


For each sample, the most intact and evenly stained section was used for image acquisition. A Leica DM2500 confocal microscope (Leica Biosystems Inc., Buffalo Grove, IL) was used for fluorescent image capture in a dark room with identical settings. A $561 \mathrm{~nm}$ excitation laser was used at a gain of 800 and $60 \%$ power, with a $1.5 \mathrm{x}$ optical zoom on a 40x oil immersion lens. Emission spectra were filtered to $640-750 \mathrm{~nm}$ to select for signals coming from stored lipids rather than phospholipids of cellular membranes (Prats et al., 2013). By using confocal microscopy each optical section was reduced to $1.33 \mu \mathrm{m}$ thick, offsetting the relative "thickness" $(25 \mu \mathrm{m})$ of the tissue section itself. Eight images (without overlap or other tissue types) were captured from each muscle section, minimizing inclusion of tissue tears or other artifacts. Z-stack focusing was performed to ensure the sharpest, most punctate, signal from intramyocellular lipid droplets possible. Final images were exported as TIFFs to preserve data integrity (Figure 6).

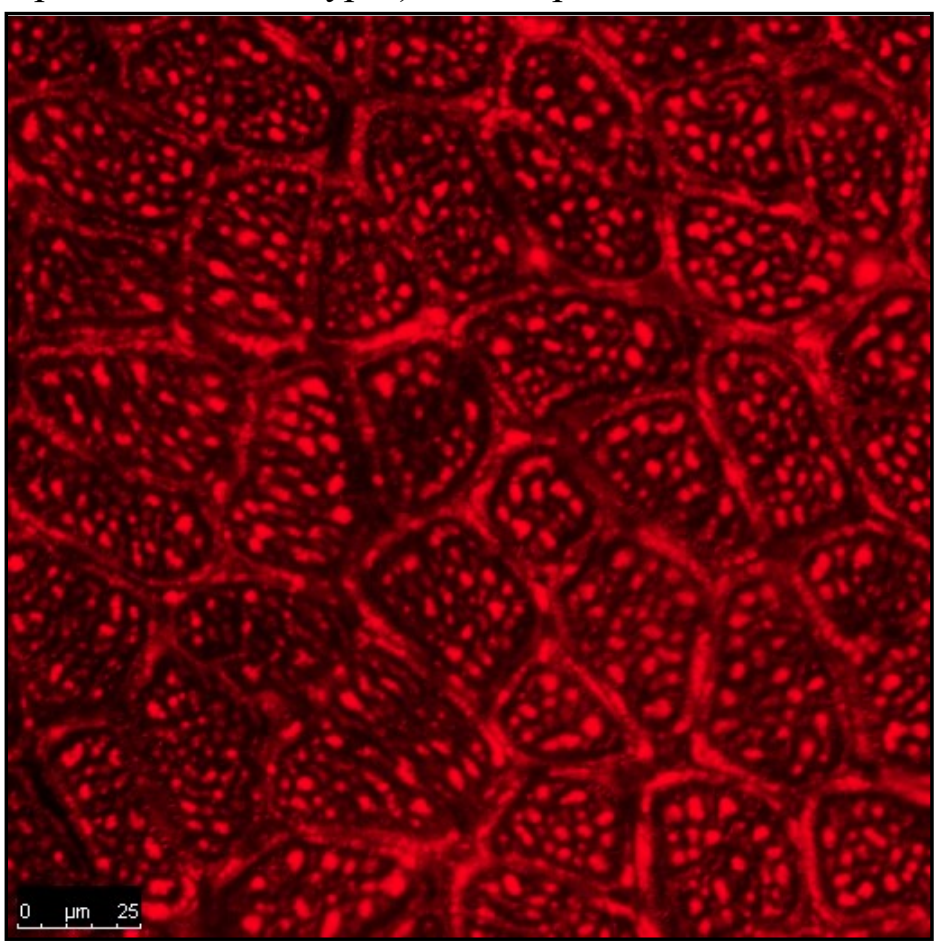

Figure 6. Fluorescent microscopy of $O$. mykiss red muscle tissue stained with oil red $\mathrm{O}, 40 \mathrm{x}$ with 1.5 optical zoom. 
For lipid accumulation quantification ImageJ (FIJI) was used (Goodpaster et al., 2000, Schindelin et al., 2012). A macro script was written to achieve the following: set image size to $183.33 \mu \mathrm{m}$ by $183.33 \mu \mathrm{m}$, convert to 8 -bit, and measure tissue area. Then, with a second string of macro script lipid droplet signal minus any artifacts was measured, and the resulting images were saved as JPEGs for record keeping. Tissue and lipid droplet signals were differentiated by signal level on a 0-255 scale LUT, where tissue threshold was 10-70, and lipid signal was 38-70 (Goodpaster et al., 2000). With these two measurements, lipid $\%$ could be calculated. All fluorescent images were analyzed with the same process using the Batch Process command.

Two major environmental variables of selective relevance to the energetic requirements of migration were considered: migratory distance $(\mathrm{km})$, and elevation $(\mathrm{m})$. Generally, these variables are covariates, and as such were successfully combined into a single measure of "difficulty" by Crossin and colleagues (2004) by modifying the standard physics equation for work. Combining both environmental factors in this way results in an assessment of migratory work in terms of energetic cost, where work $=$ 0.001(distance $(\mathrm{km}) \mathrm{x}$ elevation $(\mathrm{m}))$.

Migration distance and elevation were measured using the online Streamer Tool produced by the United States Geological Survey (USGS, 2015), supplemented with information from each hatchery's publicly available management plan. Coastal migration difficulty ranged from 0.21 (Nestucca) to 69 (S. Santiam), while inland migration difficulty was much greater with a range from 57 (Umatilla) to 520 (Imnaha), each in terms of work $(\mathrm{km} * \mathrm{~m})$. 
Red muscle lipid content was standardized for fish size by dividing lipid \% by individual body condition and then $\log _{10}$ transformed to achieve a normal distribution; any reported stored lipid refers to this measure, also termed "lipid accumulation index", or LAI (Goodpaster et al., 2000). Note that applying a log transformation to any number less than one will produce a negative number. For all analyses, significance levels were set at $\alpha=0.05$. Clonal fish are not included in study results due to their identical genetics, and thus do not constitute biological replicates, but rather were used to confirm the quantification methods and illustrate variation produced by purely exogenous factors. All statistical analysis performed and figures generated utilized JMP Pro ${ }^{\circledR}$ (Version 14, SAS Institute Inc., Cary, NC, 1989-2019). 


\section{RESULTS AND DISCUSSION}

\subsection{RESULTS}

Physical measurements of the juvenile steelhead sampled are summarized in Table 2. Coastal fish exhibited a lower mean body condition than inland fish ( $\mathrm{DF}=100$, $\mathrm{p}<0.0001$ ), as well as significantly lower length and weight measurements (Length: DF $=125, \mathrm{p}<0.0001$, Weight: DF $=88, \mathrm{p}<0.0001)$. For both subspecies, body condition

Table 2. Biological characteristics of pre-release juvenile steelhead summarized by subspecies and hatchery stock, means are reported \pm standard deviation $(\mathrm{n}=140)$.

\begin{tabular}{lllllll}
\hline Subspecies & Stock & $\mathrm{n}$ & $\begin{array}{l}\text { Sex } \\
(\text { female, male })\end{array}$ & $\begin{array}{l}\text { Length } \\
(\mathrm{mm})\end{array}$ & Weight $(\mathrm{g})$ & $\begin{array}{l}\text { Body Condition } \\
(\mathrm{K})\end{array}$ \\
\hline Coastal & & 80 & 40,40 & $166 \pm 30$ & $72.6 \pm 36.1$ & $1.44 \pm 0.12$ \\
\hline \multirow{6}{*}{ Nestucca } & 20 & 9,11 & $174 \pm 24$ & $81.4 \pm 29.1$ & $1.47 \pm 0.092$ \\
& Lewis & 20 & 10,10 & $173 \pm 19$ & $76.4 \pm 24.9$ & $1.44 \pm 0.069$ \\
& Kalama & 20 & 13,7 & $134 \pm 17$ & $36.4 \pm 14.7$ & $1.44 \pm 0.11$ \\
& S. & 20 & 8,12 & $184 \pm 30$ & $96.1 \pm 40.8$ & $1.43 \pm 0.17$ \\
& Santiam & & & & & \\
& & 60 & 23,37 & $195 \pm 29$ & $121 \pm 56.2$ & $1.54 \pm 0.14$ \\
\hline \multirow{4}{*}{ Inland } & & & & & & \\
& Umatilla & 20 & 5,15 & $174 \pm 25$ & $85.7 \pm 38.1$ & $1.54 \pm 0.11$ \\
& Deschutes & 20 & 10,10 & $220 \pm 22$ & $174 \pm 53.0$ & $1.59 \pm 0.18$ \\
& Imnaha & 20 & 8,12 & $190 \pm 19$ & $104 \pm 32.0$ & $1.47 \pm 0.091$ \\
\hline
\end{tabular}

decreased with greater migratory difficulty $\left(\right.$ Coastal $\mathrm{R}^{2}=0.11$, Inland $\left.\mathrm{R}^{2}=0.05\right)$; this occurred significantly for coastal fish $(F(1,75)=9.72, p=0.0026)$. 
Hatchery-level effects were analyzed with as much scrutiny as possible given the somewhat limited amount of information available. Even though dietary fat and protein were slightly different between feeds at some of the hatcheries (Appendix B), neither component had a statistically significant relationship to LAI in juvenile fish (Min. Fat\%: $\mathrm{R}^{2}=0.001, \mathrm{~F}(1,65)=0.06, \mathrm{p}=0.8031$, Min. Protein $\%: \mathrm{R}^{2}=0.023, \mathrm{~F}(1,65)=1.55, \mathrm{p}=$ 0.2173). Additionally, rearing temperatures across hatcheries were not significantly different $(F(6,7)=0.24, p=0.9469$, Appendix C: Figure $C 2)$, and were unrelated to stored lipids $(p=0.8670)$. Initial exploration of the data collected included multivariate correlation matrices as well as bootstrap forest partitioning to inform predictive power of variables for muscular lipid content.

LAI was not significantly different between male and female juvenile fish as a whole $(\mathrm{DF}=60, \mathrm{p}=0.482)$, but did differ significantly when assessing precocious (i.e., early sexually maturing) males independently $(n=3, D F=13, p<0.0001$, Appendix C: Figure C1). Precocious males were subsequently removed from further analyses due to their different physiological state and status as outliers. Precocious males are parr that have put energy into becoming sexually mature rather than into preparing to migrate, and will remain in freshwater (Quinn, 2005). Mean muscular lipid stores were significantly higher in coastal fish than inland fish $(\mathrm{DF}=50, \mathrm{p}=0.0020$, coastal $\mathrm{n}=38$, inland $\mathrm{n}=29$, Figure 7). However, for the coastal stocks sampled, mean LAI was not significantly different between groups (Welch's test, F-Ratio $=0.261, \mathrm{DF}=3, \mathrm{p}=0.8522$ ), nor was there a significant relationship in lipid storage by migratory difficulty (Figure 8). For the inland stocks sampled, lipid storage significantly increased with migratory difficulty (Figure $\left.8 . \mathrm{R}^{2}=0.34, \mathrm{~F}(1,27)=13.8, \mathrm{p}=0.0009\right)$. 


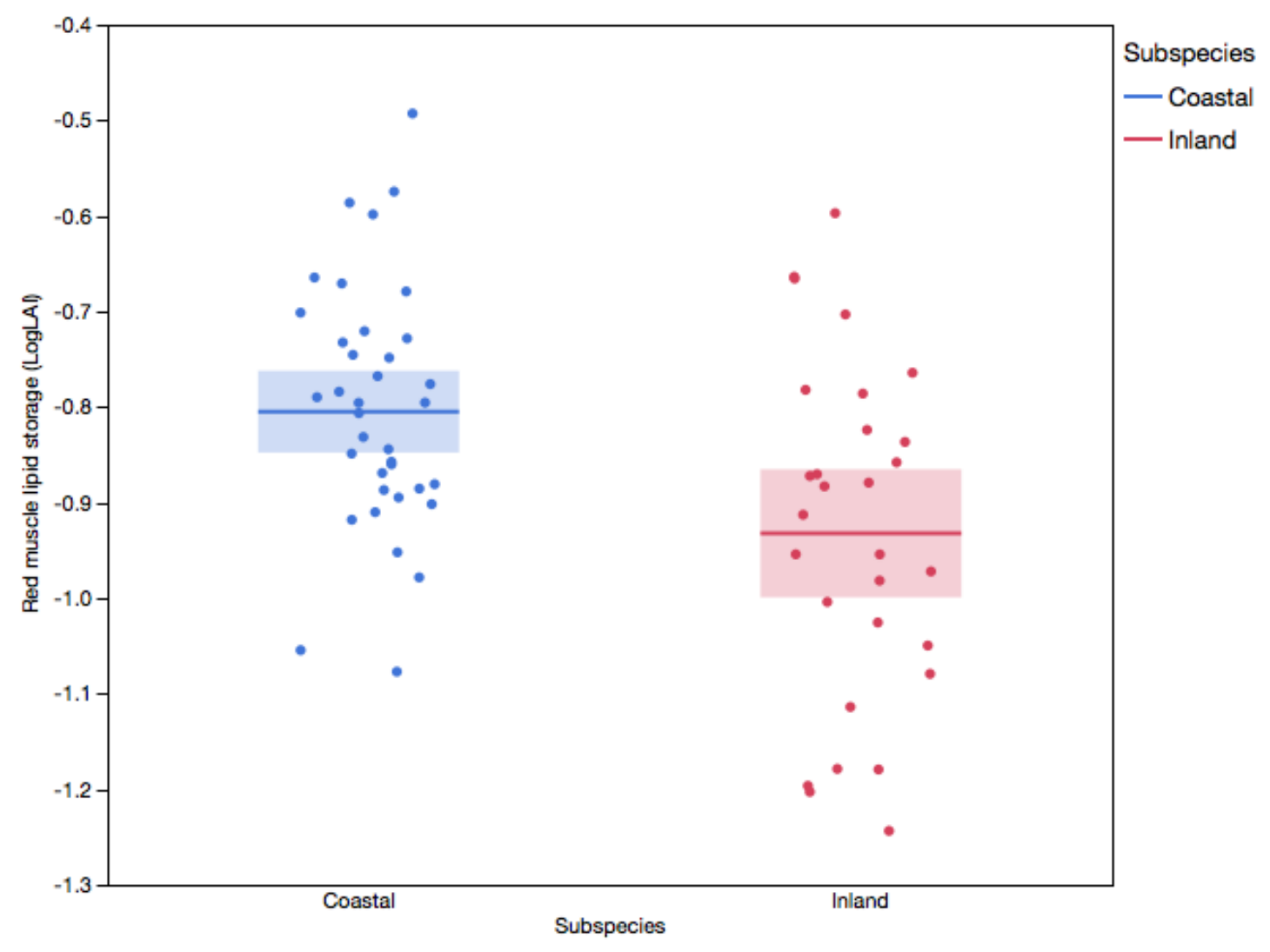

Figure 7. Red muscle lipid storage in juvenile hatchery steelhead pre-release by subspecies. Shaded areas refer to $95 \%$ CI (coastal $n=38$, inland $n=29$ ). 


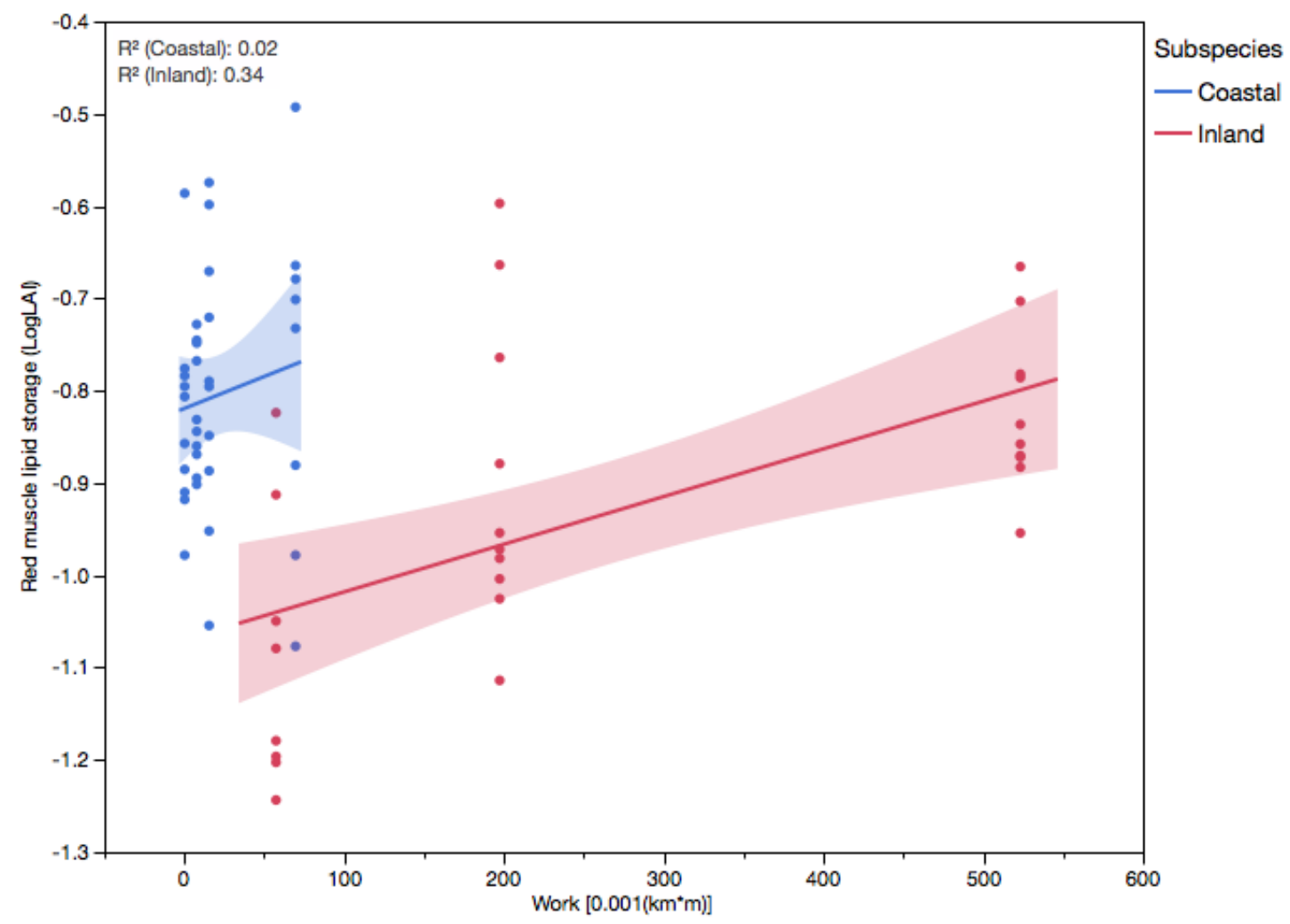

Figure 8. Red muscle lipid storage in juvenile hatchery steelhead pre-release by migratory difficulty (work) from either the coastal or inland subspecies. Shaded areas refer to $95 \%$ CI (coastal $n=38$, inland $n=29)$.

In order to assess the relationship between stored lipids and the measured variables more fully, a series of generalized linear models were constructed for the inland subspecies stocks. For the final model of inland LAI, migratory difficulty and number of dam passages produced the best fit according to the lowest Akaike Information Criterion corrected (AICc) for small sample size, and a significant negative log-likelihood ( $\mathrm{DF}=2$, $\left.\mathrm{X}^{2}=0.0002\right)$. Number of dam passages (Appendix B) in migratory route by each stock was the only measured variable important to model fit aside from migratory difficulty, even with inclusion of factors such as hatchery, mean rearing temperature $\left({ }^{\circ} \mathrm{C}\right)$, collection date, and feed composition $(\mathrm{p}=0.0309)$. The model equation is: $\log (\mathrm{LAI})=$ 0.0010969 (work) - 0.047166(dams) - 1.017718, and fit is shown visually in Figure 9. 
Further assessment of the model was performed by plotting actual values of LAI versus predicted values of LAI by the model equation (Bivariate fit correlation $=0.66, p<$ 0.0001). A statistical summary can be found in Table 3 .

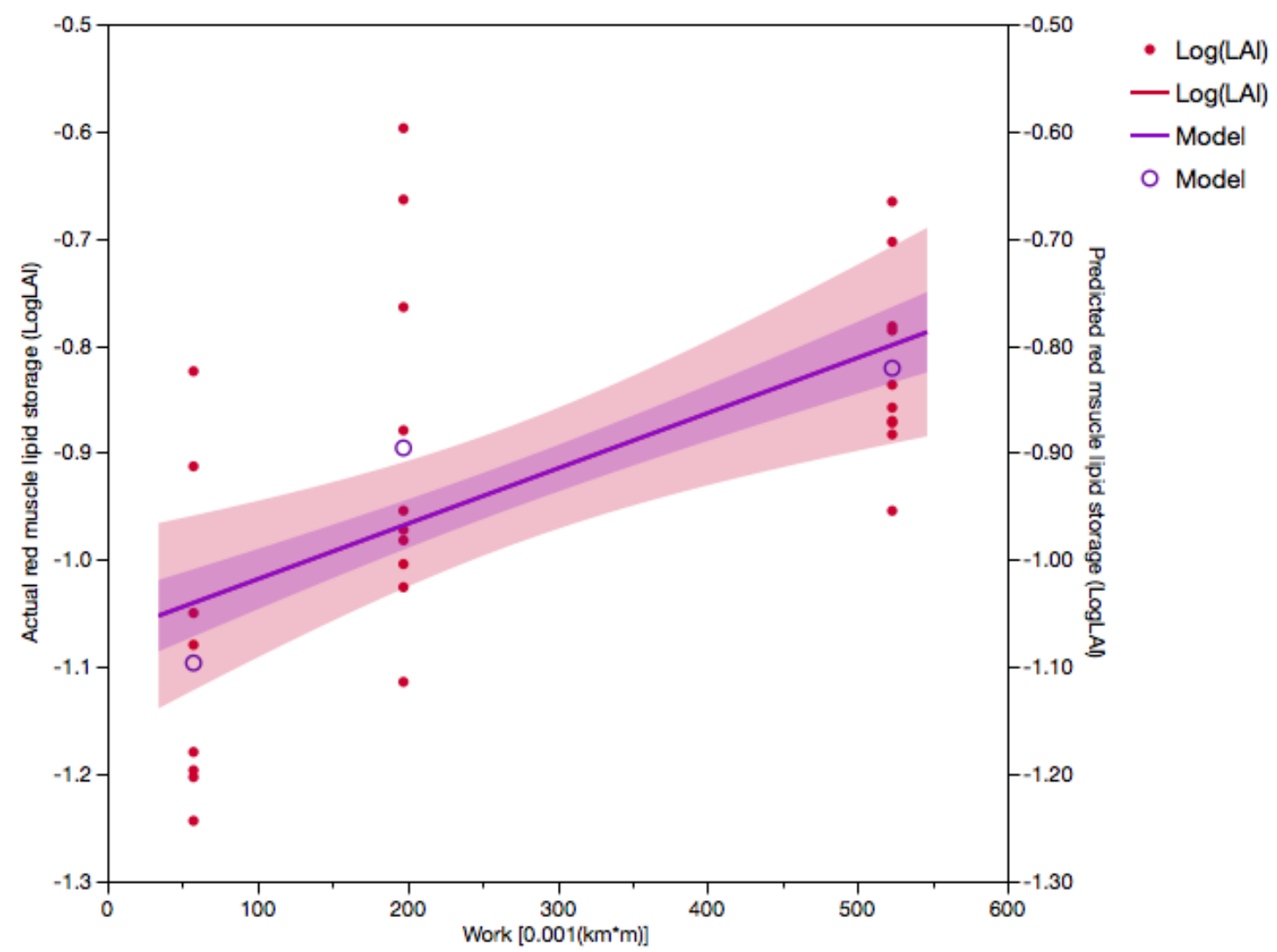

Figure 9. Measured red muscle lipid storage in inland juvenile steelhead pre-release by migratory difficulty (work) in red, and predicted values from a model equation including number of dam passages per stock in purple. Number of dams encountered by each stock from left to right are Umatilla (3), Deschutes (2), and Imnaha (8). Model equation: $\log (\mathrm{LAI})=0.0010969($ work $)-0.047166($ dams $)-1.017718$. Shaded areas refer to $95 \%$ CI (inland $=29$ ). 
Table 3. Summary of Fit and ANOVA for actual juvenile red muscle Log(LAI) versus modeled values $(n=29)$.

\begin{tabular}{|c|c|c|c|c|c|}
\hline \multirow{6}{*}{$\begin{array}{l}\text { Summary of } \\
\text { Fit }\end{array}$} & & \multicolumn{4}{|l|}{ Value } \\
\hline & $\mathrm{R}^{2}$ & 0.44 & & & \\
\hline & $\mathrm{R}^{2}$ Adjusted & 0.42 & & & \\
\hline & $\begin{array}{l}\text { Root Mean Square } \\
\text { Error }\end{array}$ & 0.13463 & & & \\
\hline & Mean of Response & -0.9322 & & & \\
\hline & $\begin{array}{l}\text { Observations (or } \\
\text { Sum Weights) }\end{array}$ & 29 & & & \\
\hline \multirow[t]{5}{*}{ ANOVA } & & DF & Sum of Squares & Mean Square & F-Ratio \\
\hline & Model & 1 & 0.37910 & 0.37910 & 20.9145 \\
\hline & Error & 27 & 0.48940 & 0.01812 & \\
\hline & C. Total & 28 & 0.86850 & & Prob. $>$ F \\
\hline & & & & & $<0.0001$ \\
\hline
\end{tabular}

\subsection{DISCUSSION}

Assessing the roles of genetic and environmental effects on physiology can be difficult in a population, both from a conceptual and statistical perspective. However, a case can be made for the genetic level of control on red muscle lipid accumulation when comparing the Umatilla (inland) and S. Santiam (coastal) stocks. Migratory difficulty is relatively close between these groups, and feed composition for these two groups was identical in terms of protein and fat content (Appendix A). While rearing temperature ranges overlapped between the two hatcheries, the means were different with Umatilla at 12.2 ${ }^{\circ} \mathrm{C}$, and S. Santiam at $7.2^{\circ} \mathrm{C}$. According to Sloat and Reeves (2014), at lower temperatures physiological allocation shifts juveniles towards freshwater maturation. 
Within the S. Santiam stock there were three precocious males among the sampled 20 fish, and among the Umatilla stock there was only one precocious male.

Based on just environmental effects, particularly temperature, one would expect the remaining S. Santiam fish to be less prepared to migrate than their Umatilla agemates. However, lipid storage in red muscle was significantly higher in the coastal S. Santiam fish than the inland Umatilla juveniles $(\mathrm{DF}=13, \mathrm{p}=0.0019)$. In this case, lipid accumulation followed genetic (subspecies) trends over potentially contraindicated hatchery effects (Figure 10).

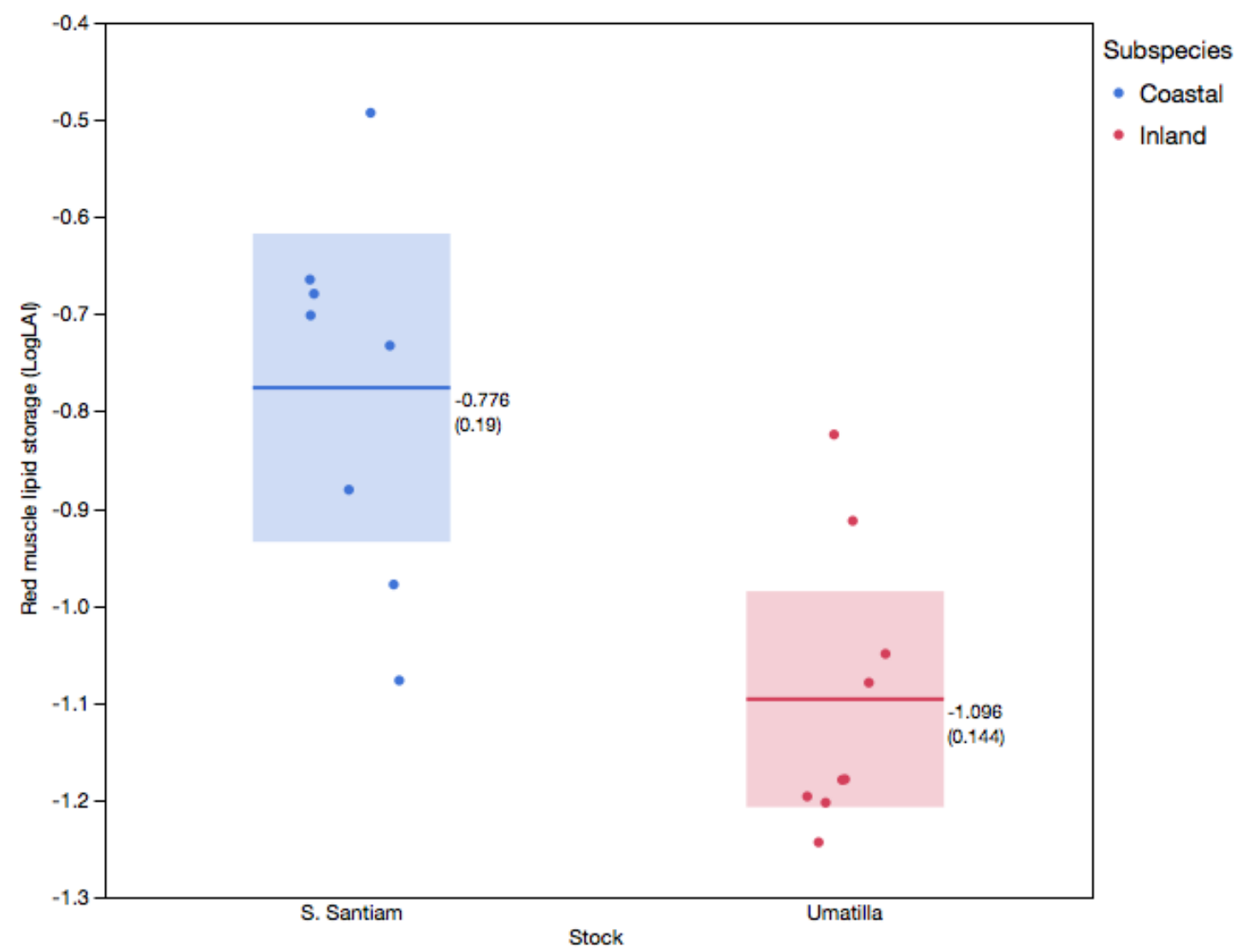

Figure 10. Comparison of juvenile $O$. mykiss lipid storage in red muscle by stock and subspecies (S. Santiam $n=8$, Umatilla $n=9$ ). Shaded area refers to a $95 \% \mathrm{CI}$. 
While "hatchery effects" constitute a known environmental pressure on propagated stocks (Flagg et al., 2000), within the present study rearing conditions were not statistically significant in regards to lipid content of red muscle. In O. mykiss specifically, skeletal muscle lipid deposition is primarily genetically driven (Quillet et al., 2005, Kaneko et al. 2016). Given what we know about the development of juvenile salmonids and the role of energy budgets in the physiological "decision" to migrate, hatchery environment may not have as significant an effect on red muscle lipid content as on other biological factors (Forseth et al., 1999, Nichols et al., 2008).

While there was a high level of variation of LAI within stocks, quantification methods were supported by a significantly lower LAI in precocial hatchery males (Appendix C: Figure $\mathrm{C} 1, \mathrm{DF}=13.1, \mathrm{p}<0.0001)(\mathrm{Quinn}, 2005)$. Inter-individual variation due to exogenous factors despite identical genetics of clonal fish also supports this level of variation (Appendix C: Figure C3). O. mykiss are well known for their partially migratory nature, arising from the strategic ability to remain in freshwater as resident rainbow trout, or to delay maturity and migrate seaward. This fitness trade-off is informed in part by individual energy budget as well as environmental cues and genetics (Gross, 1987, Pavlov et al., 2007, Ohms et al., 2014). Conceivably, some of the differences in lipid deposits within stocks could be due to the variable life history options in this species.

Furthermore, the lack of statistical difference in lipid status of coastal juveniles between hatchery stocks may be due to underlying genetic similarity. Three of the four coastal stocks have a common Skamania Hatchery origin. In 1963 the Skamania Hatchery initiated a cross of wild Washougal River and wild Klickitat River steelhead 
populations, and has been propagating this crossed stock with returning Skamania hatchery adults since. Numerous hatchery stocks have been established with Skamania eggs, and now are sustained by their own local returns for broodstock (Skamania Hatchery and Genetic Management Plan, 2012). Unfortunately, this was not apparent in the initial stock selection before study sampling.

Alternatively, the lipid content of red muscle could have an upper threshold. Coastal lipid stores were significantly higher than the inland samples- perhaps juvenile fish populations that are in relatively close proximity to marine waters must maximize their stored fuel deposits (Figure 7). In addition to endurance swimming, smoltification itself also requires significant lipid metabolism (Sheridan and Kao, 1998, Quinn, 2005). Development time is accelerated with decreased transit time to offshore feeding grounds (Daly et al., 2014). Juvenile salmonids need to transition into their marine forms and leave estuaries quickly to avoid avian predation (Kennedy et al. 2014), and survival increases with faster movement offshore (Goetz et al., 2014). This line of reasoning is supported by the lower mean body condition in the coastal stocks. Smaller, more hydrodynamic fish reach the ocean at a faster rate (Giorgi et al., 1997). Juvenile steelhead body condition in these stocks had a slight negative relationship with migratory difficulty $\left(\mathrm{R}^{2}=0.11, \mathrm{p}=0.0026\right)$. In adult salmonids, the more slender morphology associated with low condition factor and hydrodynamic efficiency is selected for as migratory difficulty increases (Crossin et al., 2004, Chapman et al., 2015).

For inland juvenile steelhead stored lipid increased with migration difficulty as expected, and the significance of dam passages in the model corresponds to dam's understood impact on aquatic migration. River impoundments increase juvenile travel 
time (Berggren and Filardo, 1993), and can have a compounding effect on fish survival (Elder et al., 2016). It certainly follows that increased migratory difficulty in the form of dams would also influence juvenile steelhead metabolic requirements and fuel storage (Flodmark et al., 2004). The generalized linear model explained 44\% of inland LAI variation (Table 3). Further investigation is warranted to further explore this crucial period of Oncorhynchus life history. 


\section{CONCLUSION}

Stored lipids are the primary fuel for endurance swimming in fish (Magnoni and Weber, 2007), and are known to be accumulated at higher levels in adult Oncorhynchus as migration difficulty increases (Crossin et al., 2004). Yet it is unknown how these mechanisms are utilized by juvenile fish during their seaward migration. This is of particular concern given the value of these salmonids, and the volume at which they are released by hatcheries to replenish local populations (Halverson, 2010). The driving goal of this study was to investigate the relationship between migration difficulty and lipid storage in pre-migration juvenile steelhead, as well as to characterize any physiological differences between the coastal and inland subspecies within the Columbia River Basin supplementation program.

For sampled inland juvenile stocks, stored lipids increased with migratory difficulty and number of dam passages. While the coastal stocks sampled had no significant change in LAI with migratory difficulty, they did have a significantly higher level of pre-migration intramyocellular lipids compared to their inland age-mates. Higher lipid stores combined with an enhanced hydrodynamic morphology, could be due to a demand for faster smoltification, with the reduced transit time to estuarine waters compared to inland fish.

Although direct causal relationships cannot be inferred from these results, they do make gains in illustrating the energetic mechanisms underlying juvenile steelhead migration. Lipids were a focal point in this research because of their essential role in salmonid preparation for migration. Additionally, the optimization of a staining and analysis technique for teleosts that has previously only been used in mammalian 
vertebrates may allow more specific measurement of lipids than proximate composition analyses. Currently, no other studies have looked at juvenile lipid storage in the context of subspecies or migratory differences. This scientific gap is especially surprising considering Oncorhynchus is a genus of great value; they play a critical role in the recreational economy, are a focus of massive conservation efforts, key to commercial fishing, important to ecosystem vitality, and an essential element of local culture.

As is the nature of research, further areas for inquiry have been sparked by this study. To further elucidate the physiology of migratory preparation, white muscle biopsies collected from sampled parr could be assessed for glycolytic fuel stores to investigate any links to migratory or subspecies level differences (Thibault et al., 1996, Dickhoff et al., 1997). Also, red muscle tissue-specific comparisons could be made to wild populations. The well-documented behavioral, physiological, and genetic differences between wild and hatchery-reared fish have been reviewed both by Flagg et al. (2000) and Naish et al. (2007). Decisive traits such as fuel storage are certainly pertinent to monitor in large-scale management programs; particularly because wild fish have higher survival rates than hatchery fish for both the seaward and spawning migrations (Chilcote et al., 1986, Keefer at al., 2018). And finally, an investigation of how smoltification rates may be related to fish energetics and migratory transit time to marine feeding grounds may be equally as important to understanding this critical developmental period in the iconic Oncorhynchus. 


\section{REFERENCES}

Augerot, X., and Foley, D. N. (2005). Atlas of Pacific Salmon. University of California Press.

Bams, R. (1976). Survival and propensity for homing as affected by presence or absence of locally adapted paternal genes in two transplanted populations of pink salmon (Oncorhynchus gorbuscha). Journal of the Fisheries Research Board of Canada, 33(12), 2716-2725.

Beckman, B. R., Larsen, D. A., Sharpe, C., Lee-Pawlak, B., Schreck, C. B., \& Dickhoff, W. W. (2004). Physiological status of naturally reared juvenile spring chinook salmon in the Yakima River: seasonal dynamics and changes associated with smolting. Transactions of the American Fisheries Society, 129(3), 727-753.

Behnke, R. J. (2002). Trout and salmon of North America. Free Press.

Benador, I. Y., Veliova, M., Mahdaviani, K., Petcherski, A., Wikstrom, J. D., Assali, E. A., ... Shirihai, O. S. (2018). Mitochondria bound to lipid droplets have unique bioenergetics, composition, and dynamics that support lipid droplet expansion. Cell Metabolism, 27(4), 869-885.e6.

Berggren, T. J., \& Filardo, M. J. (2004). An analysis of variables influencing the migration of juvenile salmonids in the Columbia River Basin. North American Journal of Fisheries Management, 13(1), 48-63.

Bradford, M., Keefer, M. L., Peery, C. A., \& High, B. (2009). Behavioral thermoregulation and associated mortality trade-offs in migrating adult steelhead (Oncorhynchus mykiss): variability among sympatric populations. Canadian Journal of Fisheries and Aquatic Sciences, 66(10), 1734-1747.

Busby, P. J., Wainwright, T. c, Bryan, G. J., Lierheimer, L. J., Waples, R. S., Waknitz, F. W., \& Lagomasino, I. V. (1996). Status review of west coast steelhead from Washington, Idaho, Oregon, and California.

Cedar Creek Hatchery. (2016). Hatchery and genetic management plan (HGMP): summer steelhead (Oncorhynchus mykiss) stock 47. Oregon Department of Fish and Wildlife.

Chapman, B. B., Hulthén, K., Brönmark, C., Nilsson, P. A., Skov, C., Hansson, L. A., \& Brodersen, J. (2015). Shape up or ship out: migratory behaviour predicts morphology across spatial scale in a freshwater fish. Journal of Animal Ecology, 84(5), 1187-1193. 
Chilcote, M. W., Leider, S. A., \& Loch, J. J. (1986). Differential reproductive success of hatchery and wild summer-run steelhead under natural conditions. Transactions of the American Fisheries Society, 115(5), 726-735.

Columbia River Inter-Tribal Fish Commission. (2019). Tribal Salmon Culture: Salmon Culture of the Pacific Northwest Tribes. Retrieved April 16, 2019, from https://www.critfc.org/salmon-culture/tribal-salmon-culture/.

Cotillard, A., Kennedy, S. P., Kong, L. C., Prifti, E., Pons, N., Le Chatelier, E., ... Layec, S. (2013). Dietary intervention impact on gut microbial gene richness. Nature, 500(7464), 585-588.

Crossin, G. T., Hinch, S. G., Farrell, A. P., Higgs, D. A., Lotto, A. G., Oakes, J. D., \& Healey, M. C. (2004). Energetics and morphology of sockeye salmon: Effects of upriver migratory distance and elevation. Journal of Fish Biology, 65(3), 788810.

Daly, E. A., Scheurer, J. A., Brodeur, R. D., Weitkamp, L. A., Beckman, B. R., \& Miller, J. A. (2014). Juvenile steelhead distribution, migration, feeding, and growth in the columbia river estuary, plume, and coastal waters. Marine and Coastal Fisheries, $6(1), 62-80$.

Dickhoff, W. W., Beckman, B. R., Larsen, D. A., \& Moriyama, S. (1997). The role of growth in endocrine regulation of salmon smoltification. Fish Physiology and Biochemistry, 17, 231-236.

Elder, T., Woodley, C. M., Weiland, M. A., \& Strecker, A. L. (2016). Factors influencing the survival of outmigrating juvenile salmonids through multiple dam passages: an individual-based approach. Ecology and Evolution, 6(16), 5881-5892.

Fallert Creek Hatchery. (2012). Hatchery and genetic management plan (HGMP): Kalama summer steelhead (Oncorhynchus mykiss). Washington Department of Fish and Wildlife.

Flagg, T. A., Berejikian, B. A., Colt, J. E., Dickhoff, W. W., Harrell, L. W., Maynard, D. J., ... Mahnken, C. V. W. (2000). Ecological and behavioral impacts of artificial production strategies on the abundance of wild salmon populations: a review of practices in the Pacific Northwest. NOAA Technical Memorandum. NMFSNWFSC-XX.

Fleming, I. A., and Gross, M. R. (1990). Latitudinal clines : a trade-off between egg number and size in Pacific salmon. Ecology, 71(1), 1-11. 
Flodmark, L. E. W., VØllestad, L. A., \& Forseth, T. (2004). Performance of juvenile brown trout exposed to fluctuating water level and temperature. Journal of Fish Biology, 65(2), 460-470.

Forseth, T., Næsje, T. F., Jonsson, B., \& Hårsaker, K. (1999). Juvenile migration in brown trout: a consequence of energetic state. Journal of Animal Ecology, 68(4), 783-793.

Fraser, D. J., Weir, L. K., Bernatchez, L., Hansen, M. M., \& Taylor, E. B. (2011). Extent and scale of local adaptation in salmonid fishes: review and meta-analysis. Heredity, 106(3), 404-420.

Giorgi, A. E., Hillman, T. W., Stevenson, J. R., Hays, S. G., \& Peven, C. M. (1997). Factors that influence the downstream migration rates of juvenile salmon and steelhead through the hydroelectric system in the Mid-Columbia River Basin. North American Journal of Fisheries Management, 17(2), 268-282.

Goetz, F. A., Jeanes, E., Moore, M. E., \& Quinn, T. P. (2015). Comparative migratory behavior and survival of wild and hatchery steelhead (Oncorhynchus mykiss) smolts in riverine, estuarine, and marine habitats of Puget Sound, Washington. Environmental Biology of Fishes, 98(1), 357-375.

Goodpaster, B. H., Theriault, R., Watkins, S. C., Kelley, D. E., Bogardus, C., Lillioja, S., ... al., et. (2000). Intramuscular lipid content is increased in obesity and decreased by weight loss. Metabolism: Clinical and Experimental, 49(4), 467-72.

Gross, M. R. (1987). Evolution of diadromy in fishes. American Fisheries Society Symposium.

Halverson, A. (2010). An Entirely Synthetic Fish: How Rainbow Trout Beguiled America and Overran the World. New Haven: Yale University Press.

Helfield, J. M., and Naiman, R. J. (2001). Effects of salmon-derived nitrogen on riparian forest. Ecology, 82(9), 2403-2409.

Kaneko, G., Shirakami, H., Hirano, Y., Oba, M., Yoshinaga, H., Khieokhajonkhet, A., ... Ushio, H. (2016). Diversity of lipid distribution in fish skeletal muscle. Zoological Science, 33, 170-178.

Keefer, M. L., Wertheimer, R. H., Evans, A. F., Boggs, C. T., \& Peery, C. A. (2009). Iteroparity in Columbia River summer-run steelhead (Oncorhynchus mykiss): implications for conservation. Canadian Journal of Fisheries and Aquatic Sciences, 65(12), 2592-2605. 
Keefer, M. L., Jepson, M. A., Clabough, T. S., Johnson, E. L., Narum, S. R., Hess, J. E., \& Caudill, C. C. (2018). Sea-to-sea survival of late-run adult steelhead (Oncorhynchus mykiss) from the Columbia and Snake rivers. Canadian Journal of Fisheries and Aquatic Sciences, 75(3), 331-341.

Kendall, N. W., McMillan, J. R., Sloat, M. R., Buehrens, T. W., Quinn, T. P., Pess, G. R., ... Zabel, R. W. (2014). Anadromy and residency in steelhead and rainbow trout (Oncorhynchus mykiss): a review of the processes and patterns. Canadian Journal of Fisheries and Aquatic Sciences, 72(3), 319-342.

Kendall, N. W., Marston, G. W., \& Klungle, M. M. (2017). Declining patterns of Pacific Northwest steelhead trout (Oncorhynchus mykiss) adult abundance and smolt survival in the ocean. Canadian Journal of Fisheries and Aquatic Sciences, 74, $1275-1290$.

Kennedy, B. M., Gale, W. L., \& Ostrand, K. G. (2007). Relationship between smolt gill $\mathrm{Na}+, \mathrm{K}+$ ATPase activity and migration timing to avian predation risk of steelhead trout (Oncorhynchus mykiss) in a large estuary. Canadian Journal of Fisheries and Aquatic Sciences, 64(11),

Koopman, R., Schaart, G., \& Hesselink, M. K. (2001). Optimisation of oil red O staining permits combination with immunofluorescence and automated quantification of lipids. Histochemistry and Cell Biology, 116(1), 63-68.

Leary, S., Underwood, W., Anthony, R., Cartner, S., Lilly, E., Anthony, R., ... Division, A. W. (2013). AVMA Guidelines for the Euthanasia of Animals: 2013 Edition. American Veterinary Medical Association.

Leider, S. A., Chilcote, M. W., \& Loch, J. J. (1986). Comparative life history characteristics of hatchery and wild steelhead trout (Salmo gairdneri) of summer and winter races in the Kalama River, Washington. Canadian Journal of Fisheries and Aquatic Sciences, 43(7), 1398-1409.

Little Sheep Creek Hatchery. (2011). Hatchery and genetic management plan (HGMP): summer steelhead (Oncorhynchus mykiss) stock 029. Oregon department of Fish and Wildlife, Lower Snake River Compensation Plan.

Llewellyn, M. S., Boutin, S., Hoseinifar, S. H., \& Derome, N. (2014). Teleost microbiomes: the state of the art in their characterization, manipulation and importance in aquaculture and fisheries. Frontiers in Microbiology, 5, 207.

Lowrey, L., Woodhams, D. C., Tacchi, L., \& Salinas, I. (2015). Topographical mapping of the rainbow trout (Oncorhynchus mykiss) microbiome reveals a diverse bacterial community with antifungal properties in the skin. Applied and Environmental Microbiology, 81(19), 6915-6925. 
Lynch, A. J., Cooke, S. J., Deines, A. M., Bower, S. D., Bunnell, D. B., Cowx, I. G., ... Beard, T. D. (2016). The social, economic, and environmental importance of inland fish and fisheries. Environmental Reviews, 24(2), 115-121.

Lyons, P. P., Turnbull, J. F., Dawson, K. A., \& Crumlish, M. (2017). Phylogenetic and functional characterization of the distal intestinal microbiome of rainbow trout (Oncorhynchus mykiss) from both farm and aquarium settings. Journal of Applied Microbiology, 122(2), 347-363.

Magnoni, L. J., Patterson, D. A., Farrell, A. P., \& Weber, J.-M. (2006). Effects of longdistance migration on circulating lipids of sockeye salmon (Oncorhynchus nerka). Canadian Journal of Fisheries and Aquatic Sciences, 63(8), 1822-1829.

Magnoni, L., and Weber, J.-M. (2007). Endurance swimming activates trout lipoprotein lipase: plasma lipids as a fuel for muscle. Journal of Experimental Biology, 210(22), 4016-4023.

Mann, R., Netusil, N. R., Casavant, K. L., Huppert, D. D., Hamilton, J. R., Peters, L. L., ... Radtke, H. (2005). Economic effects from Columbia River Basin anadromous salmonid fish production. Independent Economic Analysis Board. Retrieved from https://www.nwcouncil.org/media/30505/ieab2005_1.pdf

McClure, M. M., Holmes, E. E., Sanderson, B. L., \& Jordan, C. E. (2003). A large-scale, multispecies status assessment: anadromous salmonids in the Columbia River Basin. Ecological Applications (Vol. 13).

Merwin Hatchery. (2014). Hatchery and genetic management plan (HGMP): summer steelhead (Oncorhynchus mykiss) Lewis River stock. Washington Department of Fish and Wildlife.

Montalban-Arques, A., De Schryver, P., Bossier, P., Gorkiewicz, G., Mulero, V., Gatlin, D. M., \& Galindo-Villegas, J. (2015). Selective manipulation of the gut microbiota improves immune status in vertebrates. Frontiers in Immunology. Frontiers Media SA.

Moore, J. W. (2006). Animal ecosystem engineers in streams. BioScience, 56(3), 237246.

Naiman, R. J., Alldredge, J. R., Beauchamp, D. A., Bisson, P. A., Congleton, J., Henny, C. J., ... Wood, C. C. (2012). Developing a broader scientific foundation for river restoration: Columbia River food webs. Proceedings of the National Academy of Sciences, 109(52), 21201-21207. 
Naish, K., Levin, P., Huppert, D. D., Naish, K. A., Taylor, J. E., Levin, P. S., ... Hilborn, R. (2007). An evaluation of the effects of conservation and fishery enhancement hatcheries on wild populations of salmon. Advances in Marine Biology, 53, 61194.

Nichols, K. M., Edo, A. F., Wheeler, P. A., \& Thorgaard, G. H. (2008). The genetic basis of smoltification-related traits in Oncorhynchus mykiss. Genetics, 179(3), 15591575.

Nickelson, T. E., Solazzi, M. F., \& Johnson, S. L. (2010). Use of hatchery Coho salmon (Oncorhynchus kisutch) presmolts to rebuild wild populations in Oregon coastal streams. Canadian Journal of Fisheries and Aquatic Sciences, 43(12), 24432449.

NOAA Fisheries. (2017). Species Directory: Steelhead Trout. Retrieved October 31, 2017, from https://www.fisheries.noaa.gov/species/steelhead-trout.

NOAA Office of Response \& Restoration. (2019). ERMA Northwest. Retrieved May 19, 2019, from https://erma.noaa.gov/northwest/erma.html\#/layers $=1+7963+11727+11700+1171$ $1+11704+11703+11705+11709 \& x=-117.06723 \& y=46.60666 \& z=7 \& p a n e l=$ layer .

Ohms, H. A., Sloat, M. R., Reeves, G. H., Jordan, C. E., \& Dunham, J. B. (2014). Influence of sex, migration distance, and latitude on life history expression in steelhead and rainbow trout (Oncorhynchus mykiss). Canadian Journal of Fisheries and Aquatic Sciences, 71(110), 70-80.

Pavlov, D. S., Nemova, N. N., Kirillov, P. I., Kirillova, E. A., Nefedova, Z. A., \& Vasil'eva, O. B. (2007). Lipid status and feeding habits of salmonid juveniles in the year preceding seaward migration as factors controlling their future smoltification. Journal of Ichthyology, 47(3), 241-245.

Prats, C., Gomez-Cabello, A., Nordby, P., Andersen, J. L., Helge, J. W., Dela, F., ... Ploug, T. (2013). An optimized histochemical method to assess skeletal muscle glycogen and lipid stores reveals two metabolically distinct populations of type I muscle fibers. PLoS ONE, 8(10), e77774.

Quillet, E., Le Guillou, S., Aubin, J., \& Fauconneau, B. (2005). Two-way selection for muscle lipid content in pan-size rainbow trout (Oncorhynchus mykiss). Aquaculture, 245(1-4), 49-61.

Quinn, T. P. (2005). The behavior and ecology of Pacific salmon and trout. American Fisheries Society. 
Round Butte Hatchery. (2017). Hatchery and genetic management plan (HGMP): Deschutes River summer steelhead (Oncorhynchus mykiss) ODFW stock 66. Oregon Department of Fish and Wildlife.

Sandy River Hatchery. (2013). Hatchery and genetic management plan (HGMP): summer steelhead (Oncorhynchus mykiss) South Santiam stock 24. Oregon Department of Fish and Wildlife.

Scheer, B. T. (1939). Homing instinct in salmon. The Quarterly Review of Biology, 14(4), 408-430.

Schindelin, J., Arganda-Carreras, I., Frise, E., Kaynig, V., Longair, M., Pietzsch, T., ... Cardona, A. (2012). Fiji: an open-source platform for biological-image analysis. Nature Methods, 9(7), 676-82.

Schrauwen-Hinderling, V. B., Hesselink, M. K. C., Schrauwen, P., \& Kooi, M. E. (2006). Intramyocellular lipid content in human skeletal muscle. Obesity, 14(3), 357-367.

Skamania Hatchery (2012). Hatchery and genetic management plan (HGMP): Skamania Hatchery (Washougal River) summer steelhead Oncorhynchus mykiss. Washington Department of Fish and Wildlife.

Sheridan, M. A. (1989). Alterations in lipid metabolism accompanying smoltification and seawater adaptation of salmonid fish. Aquaculture, 82(1-4), 191-203.

Sheridan, M. A., and Kao, Y. H. (1998). Regulation of metamorphosis-associated changes in the lipid metabolism of selected vertebrates. American Zoologist, $38(2), 350-368$.

Sloat, M. R., and Reeves, G. H. (2014). Individual condition, standard metabolic rate, and rearing temperature influence steelhead and rainbow trout (Oncorhynchus mykiss) life histories. Canadian Journal of Fisheries and Aquatic Sciences, 71, 491-501.

Stevens, C. E., and Hume, I. D. (1998). Contributions of microbes in vertebrate gastrointestinal tract to production and conservation of nutrients. Physiological Reviews, 78(2), 393-427.

Taylor, E. B. (1991). A review of local adaptation in Salmonidae, with particular reference to Pacific and Atlantic salmon. Aquaculture, 98(1-3), 185-207.

Thibault, M., Blier, P. U., \& Guderley, H. (1997). Seasonal variation of muscle metabolic organization in rainbow trout (Oncorhynchus mykiss). Fish Physiology and Biochemistry, 16(2), 
Umatilla Hatchery. (2017). Hatchery and genetic management plan (HGMP): Umatilla River summer steelhead (Oncorhynchus mykiss) stock 091. Oregon Department of Fish and Wildlife.

USGS. (2015). Streamer. Retrieved March 11, 2019, from https://txpub.usgs.gov/DSS/streamer/web/.

Van Doornik, D. M., Hess, M. A., Johnson, M. A., Teel, D. J., Friesen, T. A., \& Myers, J. M. (2015). Genetic population structure of Willamette River steelhead and the influence of introduced stocks. Transactions of the American Fisheries Society, $144,150-162$.

Waples, R. S., Pess, G. R., \& Beechie, T. (2008). Synthesis: Evolutionary history of Pacific salmon in dynamic environments. Evolutionary Applications, 1(2), 189206.

Weber, J.-M. (2009). The physiology of long-distance migration: extending the limits of endurance metabolism. Journal of Experimental Biology, 212(5), 593-597.

Yildirimer, C. C., \& Brown, K. H. (2018). Intestinal microbiota lipid metabolism varies across rainbow trout (Oncorhynchus mykiss) phylogeographic divide. Journal of Applied Microbiology, 125(6), 1614-1625. 


\section{APPENDIX A: LAB MATERIALS}

FIXATIVE: Paraformaldehyde (4\%), $\mathrm{pH} 7.2$

To $100 \mathrm{mls} \mathrm{npH} \mathrm{H}_{2} \mathrm{O}$ add:

8g Paraformaldehyde (granular), measured in fume hood

Add $\mathrm{NaOH}$ pellets until PF dissolves, make it basic first before heating.

Heat \& Stir $\left(<60^{\circ} \mathrm{C}\right)$; do not exceed indicated temperature!

Add more $\mathrm{NaOH}$ until solution becomes clear

Filter with P5 paper funnel

Dilute with $100 \mathrm{ml}[0.2 \mathrm{M}]$ Phosphate Buffer

Store at $4{ }^{\circ} \mathrm{C}$, shelf life is less than one month, but fixative should ideally be used within one week.

TISSUE STORAGE: Phosphate Buffer (PB) [0.1 M], pH 7.2

To $950 \mathrm{ml} \mathrm{npH} \mathrm{H}_{2} \mathrm{O}$ add:

$21.8 \mathrm{~g} \mathrm{Na}_{2} \mathrm{HPO}_{4}$ (dibasic anhydrous)

$6.4 \mathrm{~g} \mathrm{Na}_{2} \mathrm{H}_{2} \mathrm{PO}_{4}$ (monobasic anhydrous)

For $[0.1 \mathrm{M}] \mathrm{PB}$ :

Dilute 1:1 with $\mathrm{npH}_{2} \mathrm{O}, \mathrm{PB}$ solution can be kept at room temperature.

\section{CRYOPROTECTANT: Sucrose Solutions}

10\%: To 300 mls DI water, add 3 pellets PBS (Merck, $\mathrm{pH} 7.4$ ) to make a 1x solution, then add:

$30 \mathrm{~g}$ sucrose

30\%: To 300 mls DI water, add 3 pellets PBS (Merck, $\mathrm{pH} 7.4$ ) to make a 1x solution, then add:

$90 \mathrm{~g}$ sucrose

Warm in $45^{\circ} \mathrm{C}$ bath and stir until dissolved

Store at $4{ }^{\circ} \mathrm{C}$, use within 2 weeks. 


\section{SLIDES: Positive Charging Gel}

Heat three beakers of $300 \mathrm{ml} \mathrm{npH} \mathrm{H}_{2} \mathrm{O}$ in a $58{ }^{\circ} \mathrm{C}$ water bath and add:

6.0 g gelatin

Stir until dissolved, then let cool to room temperature.

Add $0.6 \mathrm{~g}$ Chromium Potassium Sulfate (III) and stir again until fully dissolved

Dunk clean glass slides in beaker with slide holder and swish and dunk for 5 minutes

Drain slides and blot if needed.

Let gel set in incubator at $37^{\circ} \mathrm{C}$ for 30 minutes to one hour.

Repeat the dunking and then incubate overnight.

Store slides at $4^{\circ} \mathrm{C}$, charge only lasts for 3-4 weeks.

STAINING: Oil Red O- stock solution and working solution

For the Stock Solution: Into $100 \mathrm{ml} 60 \%$ triethylphosphate:

Dissolve $500 \mathrm{mg}$ Oil red O (1-(2,5-Dimethyl-4-(2,5-

dimethylphenylazo)phenylazo)-2-naphthol)

Stir until fully dissolved, approximately one hour.

Store at room temperature in a dark location.

For the Working Solution: Dilute Stock Solution 3:2 with DI water.

Filter with a wetted \#42 Whatman paper cone, funnel into a clean Coplin jar. Prepare within a couple hours of use and then discard. 


\section{APPENDIX B: HATCHERY DETAILS}

Table B1. Stocks are listed in alphabetical order, and hatchery Smolt-Adult-Return rate (SAR \%) reported as most recent averages by hatchery manager or Hatchery Genetic Management Plan (HGMP).

\begin{tabular}{|c|c|}
\hline $\begin{array}{l}\text { DESCHUTES - ROUND BUTTE HATCHERY } \\
\text { ODFW Summer Steelhead, Stock \#66 } \\
\text { Oncorhynchus mykiss gairdnerii }\end{array}$ & $\begin{array}{l}\text { Round Butte Dam, } \\
\text { Madras OR, } 97741 \\
541-325-5327\end{array}$ \\
\hline $\begin{array}{l}\text { Migration pathway: } \\
\text { Pelton Regulating Dam - Deschutes River - Middle Columbia } \\
\text { Basin } \\
\text { Difficulty (work): } \\
197.4 \\
\text { Dam passages: } \\
2\end{array}$ & $\begin{array}{l}\text { Collection date: } \\
4 / 20 / 2018\end{array}$ \\
\hline $\begin{array}{l}\text { Recent SAR: } \\
2.4 \%\end{array}$ & \\
\hline $\begin{array}{l}\text { Feed: } \\
\text { EWOS Transfer RC (Min. protein } 48 \% \text {, min. fat } 24 \% \text { ) }\end{array}$ & $\begin{array}{l}\text { Rearing temperature: } \\
11^{\circ} \mathrm{C} \text { year-round }\end{array}$ \\
\hline
\end{tabular}

\begin{tabular}{|l|l|}
\hline $\begin{array}{l}\text { IMNAHA - LITTLE SHEEP CREEK HATCHERY } \\
\text { ODFW Summer Steelhead, Stock \#029 } \\
\text { Oncorhynchus mykiss gairdnerii }\end{array}$ & $\begin{array}{l}\text { Address } \\
541-922-2762 \text { (Managed } \\
\text { from Irrigon and Wallowa } \\
\text { Hatcheries) }\end{array}$ \\
\hline $\begin{array}{l}\text { Migration pathway: } \\
\text { Little Sheep Creek - Imnaha River - Snake Basin - Columbia } \\
\text { River } \\
\text { Difficulty (work): } \\
523.2 \\
\text { Dam passages: }\end{array}$ & $\begin{array}{l}\text { Collection date: } \\
8 / 22 / 2018\end{array}$ \\
\hline $\begin{array}{l}\text { Recent SAR: } \\
1.0 \%\end{array}$ & \\
\hline & \\
\hline
\end{tabular}




\begin{tabular}{|l|l|}
\hline Feed: & $\begin{array}{l}\text { Rearing temperature: } \\
10-16^{\circ} \mathrm{C} \text { seasonal } \\
\text { BioOregon BioClark Fry (Min. protein } 47 \%, \text { min. fat } 18 \%)\end{array}$ \\
\hline
\end{tabular}

\begin{tabular}{|c|c|}
\hline $\begin{array}{l}\text { KALAMA - FALLERT CREEK HATCHERY } \\
\text { WDFW Summer Steelhead, Skamania origin } \\
\text { Oncorhynchus mykiss irideus }\end{array}$ & $\begin{array}{l}\text { 1401 Kalama River Road, } \\
\text { Kalama, WA } 98625 \\
\text { 360-673-4825 }\end{array}$ \\
\hline $\begin{array}{l}\text { Juvenile migration pathway: } \\
\text { Hatchery Creek - Kalama River - Lower Columbia River } \\
\text { Difficulty (work): } \\
15.5 \\
\text { Dam passages: } \\
0\end{array}$ & $\begin{array}{l}\text { Collection date: } \\
4 / 5 / 2018\end{array}$ \\
\hline $\begin{array}{l}\text { Recent SAR: } \\
1.5 \%\end{array}$ & \\
\hline $\begin{array}{l}\text { Feed: } \\
\text { BioOregon BioSupreme (Min. protein 50\%, min. fat 20\%) }\end{array}$ & $\begin{array}{l}\text { Rearing temperature: } \\
7.2-12.8^{\circ} \mathrm{C} \text { seasonal } \\
\text { fluctuation }\end{array}$ \\
\hline
\end{tabular}

\begin{tabular}{|l|l|}
\hline $\begin{array}{l}\text { KEITHLY - WSU CRB } \\
\text { Male clonal line (YY) }\end{array}$ & $\begin{array}{l}\text { Eastlick Hall Aquaculture } \\
\text { Facility } \\
\text { Pullman, WA 99163 } \\
509-335-2473\end{array}$ \\
\hline & \\
\hline $\begin{array}{l}\text { Migration pathway: } \\
\text { Columbia River - Snake Basin - Keithly Creek }\end{array}$ & $\begin{array}{l}\text { Collection date: } \\
\text { Difficulty (work): }\end{array}$ \\
842.1 & \\
\hline Recent SAR: & \\
N/A & $\begin{array}{l}\text { Cross made: } 4 / 14 / 2018 \\
\text { Ponded: } 6 / 13 / 2016\end{array}$ \\
\hline & \\
\hline Feed: & $\begin{array}{l}\text { Rearing temperature: } \\
\text { BioOregon BioVita Fry (Min. protein } 50 \% \text {, min. fat 22\%) }\end{array}$ \\
\hline
\end{tabular}




\begin{tabular}{|l|l|}
\hline LEWIS - MERWIN HATCHERY & WDFW Summer Steelhead, Skamania origin \\
Oncorhynchus mykiss irideus & $\begin{array}{l}111 \text { Merwin Hatchery } \\
\text { Court, } \\
\text { Ariel WA, 98603 } \\
360-225-4394\end{array}$ \\
\hline & \\
\hline $\begin{array}{l}\text { Migration pathway: } \\
\text { Dewis River - Lower Columbia } \\
\text { D.76 } \\
\text { Dam passages: } \\
0\end{array}$ & $\begin{array}{l}\text { Collection date: } \\
4 / 5 / 2018\end{array}$ \\
\hline $\begin{array}{l}\text { Recent SAR: } \\
2.1 \%\end{array}$ & \\
\hline & \\
\hline $\begin{array}{l}\text { Feed: } \\
\text { EWOS Pacific (Min. protein } 47 \%, \text { min. fat } 18 \%)\end{array}$ & $\begin{array}{l}\text { Rearing temperature: } \\
5.6-16^{\circ} \mathrm{C} \text { seasonal } \\
\text { fluctuation }\end{array}$ \\
\hline
\end{tabular}

\begin{tabular}{|c|c|}
\hline $\begin{array}{l}\text { NESTUCCA - CEDAR CREEK HATCHERY } \\
\text { ODFW Summer Steelhead, Stock \#47 } \\
\text { Oncorhynchus mykiss irideus }\end{array}$ & $\begin{array}{l}33465 \text { OR-22, } \\
\text { Hebo, OR } 97122 \\
503-392-3485\end{array}$ \\
\hline $\begin{array}{l}\text { Migration pathway: } \\
\text { Nestucca River - Pacific Coast } \\
\text { Difficulty (work): } \\
0.211 \\
\text { Dam passages: } \\
0\end{array}$ & $\begin{array}{l}\text { Collection date: } \\
3 / 30 / 2018\end{array}$ \\
\hline $\begin{array}{l}\text { Recent SAR: } \\
2.5 \%\end{array}$ & \\
\hline $\begin{array}{l}\text { Feed: } \\
\text { BioOregon BioClark Fry (Min. protein 47\%, min. fat 18\%) }\end{array}$ & $\begin{array}{l}\text { Rearing temperature: } \\
4.4-19^{\circ} \mathrm{C} \text { seasonal } \\
\text { fluctuation }\end{array}$ \\
\hline
\end{tabular}




\begin{tabular}{|c|c|}
\hline $\begin{array}{l}\text { SOUTH SANTIAM - SANDY HATCHERY } \\
\text { ODFW Summer Steelhead, Skamania origin, Stock \#24 } \\
\text { Oncorhynchus mykiss irideus }\end{array}$ & $\begin{array}{l}39800 \text { SE Fish Hatchery } \\
\text { Road, } \\
\text { Sandy, OR } 97055 \\
\text { 503-668-4222 }\end{array}$ \\
\hline $\begin{array}{l}\text { Adult Collection: } \\
\text { Lower Columbia - Upper Willamette - South Santiam River - } \\
\text { Foster Dam } \\
\text { Juvenile Release: } \\
\text { Lower Columbia - Sandy River - Cedar Creek, Sandy Hatchery } \\
\text { Difficulty (work): } \\
69.6 \\
\text { Dam passages: } \\
0\end{array}$ & $\begin{array}{l}\text { Collection date: } \\
4 / 6 / 2018\end{array}$ \\
\hline $\begin{array}{l}\text { Recent SAR: } \\
2.9 \%\end{array}$ & \\
\hline $\begin{array}{l}\text { Feed: } \\
\text { EWOS Pacific (Min. protein } 47 \% \text {, min. fat } 18 \% \text { ) }\end{array}$ & $\begin{array}{l}\text { Rearing temperature: } \\
7.2^{\circ} \mathrm{C} \text { seasonal average }\end{array}$ \\
\hline
\end{tabular}

\begin{tabular}{|c|c|}
\hline $\begin{array}{l}\text { SWANSON - WSU CRB } \\
\text { Male clonal line (YY) } \\
\text { Oncorhynchus mykiss irideus }\end{array}$ & $\begin{array}{l}\text { Eastlick Hall Aquaculture } \\
\text { Facility } \\
\text { Pullman, WA } 99163 \\
\text { 509-335-2473 }\end{array}$ \\
\hline $\begin{array}{l}\text { Migration pathway: } \\
\text { Pacific Coast - Kenai Peninsula - Swanson River } \\
\text { Difficulty (work): } \\
\text { 3.13 } \\
\text { Dam passages: } \\
0\end{array}$ & $\begin{array}{l}\text { Collection date: } \\
4 / 21 / 2018\end{array}$ \\
\hline $\begin{array}{l}\text { Recent SAR: } \\
\text { N/A }\end{array}$ & $\begin{array}{l}\text { Cross made: } 3 / 20 / 2017 \\
\text { Ponded: } 5 / 23 / 2017\end{array}$ \\
\hline $\begin{array}{l}\text { Feed: } \\
\text { BioOregon BioVita Fry (Min. protein 50\%, min. fat 22\%) }\end{array}$ & $\begin{array}{l}\text { Rearing temperature: } \\
12-14^{\circ} \mathrm{C} \text { year round }\end{array}$ \\
\hline
\end{tabular}




\begin{tabular}{|c|c|}
\hline $\begin{array}{l}\text { UMATILLA - UMATILLA HATCHERY } \\
\text { ODFW Summer Steelhead, Stock \#091 } \\
\text { Oncorhynchus mykiss gairdnerii }\end{array}$ & $\begin{array}{l}73959 \text { Riverview Lane, } \\
\text { Irrigon, OR } 97844 \\
541-922-5659\end{array}$ \\
\hline $\begin{array}{l}\text { Migration pathway: } \\
\text { Umatilla River - Middle Columbia River } \\
\text { Difficulty (work): } \\
57.4 \\
\text { Dam passages: } \\
3\end{array}$ & $\begin{array}{l}\text { Collection date: } \\
4 / 7 / 2018\end{array}$ \\
\hline $\begin{array}{l}\text { Recent SAR: } \\
0.5 \%\end{array}$ & \\
\hline $\begin{array}{l}\text { Feed: } \\
\text { BioOregon BioClark Fry (Min. protein } 47 \% \text {, min. fat } 18 \% \text { ) }\end{array}$ & $\begin{array}{l}\text { Rearing temperature: } \\
12.2^{\circ} \mathrm{C} \text { seasonal average }\end{array}$ \\
\hline
\end{tabular}




\section{APPENDIX C: SUPPLEMENTARY FIGURES}

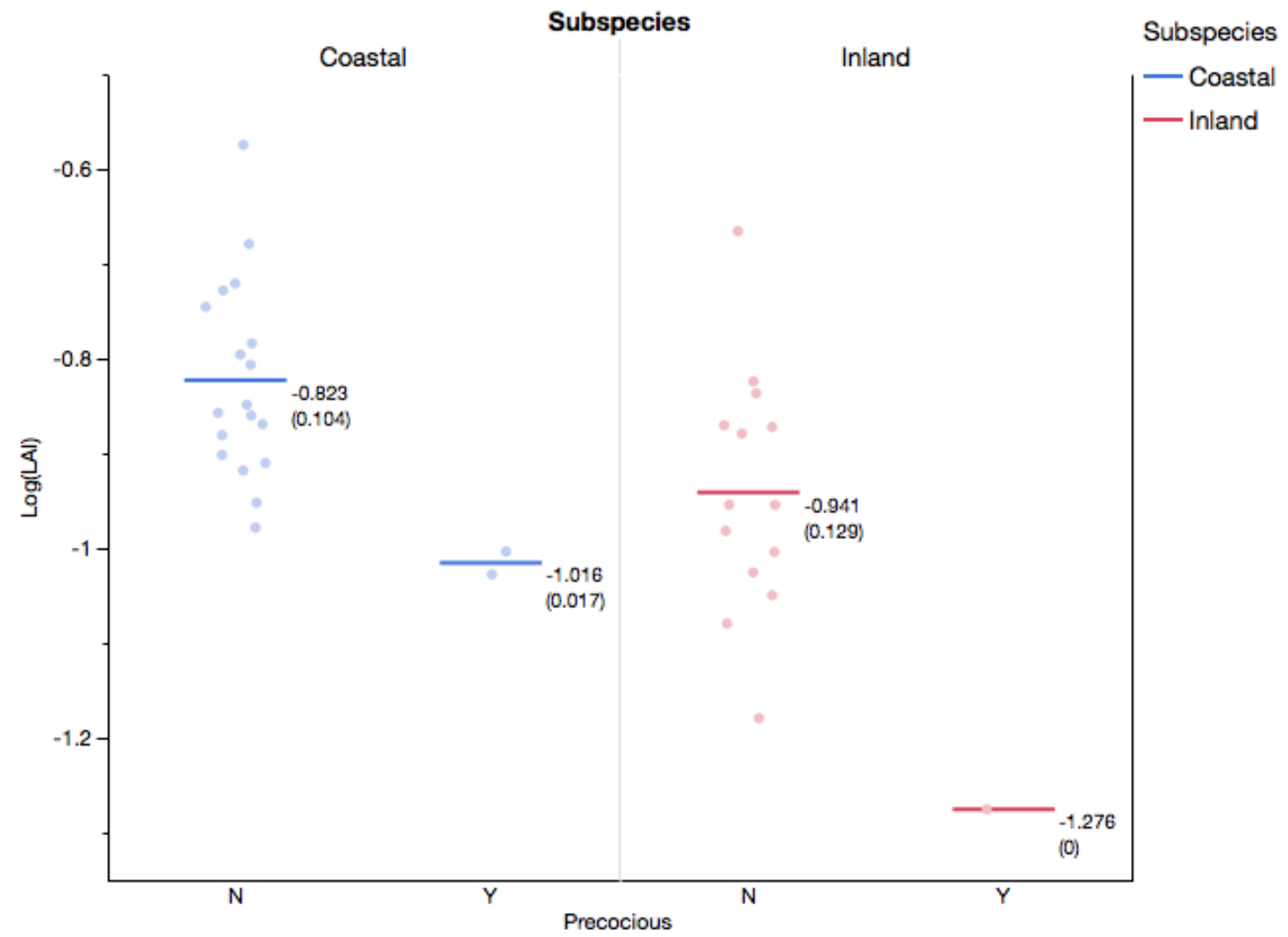

Figure $\mathrm{C} 1$. Comparison of red muscle lipid stores, $\log (\mathrm{LAI})$, in precocious and sexually immature male $O$. mykiss of the same age-class and hatchery by subspecies $(\mathrm{n}=35, \mathrm{DF}=$ $13, \mathrm{p}<0.0001)$. 


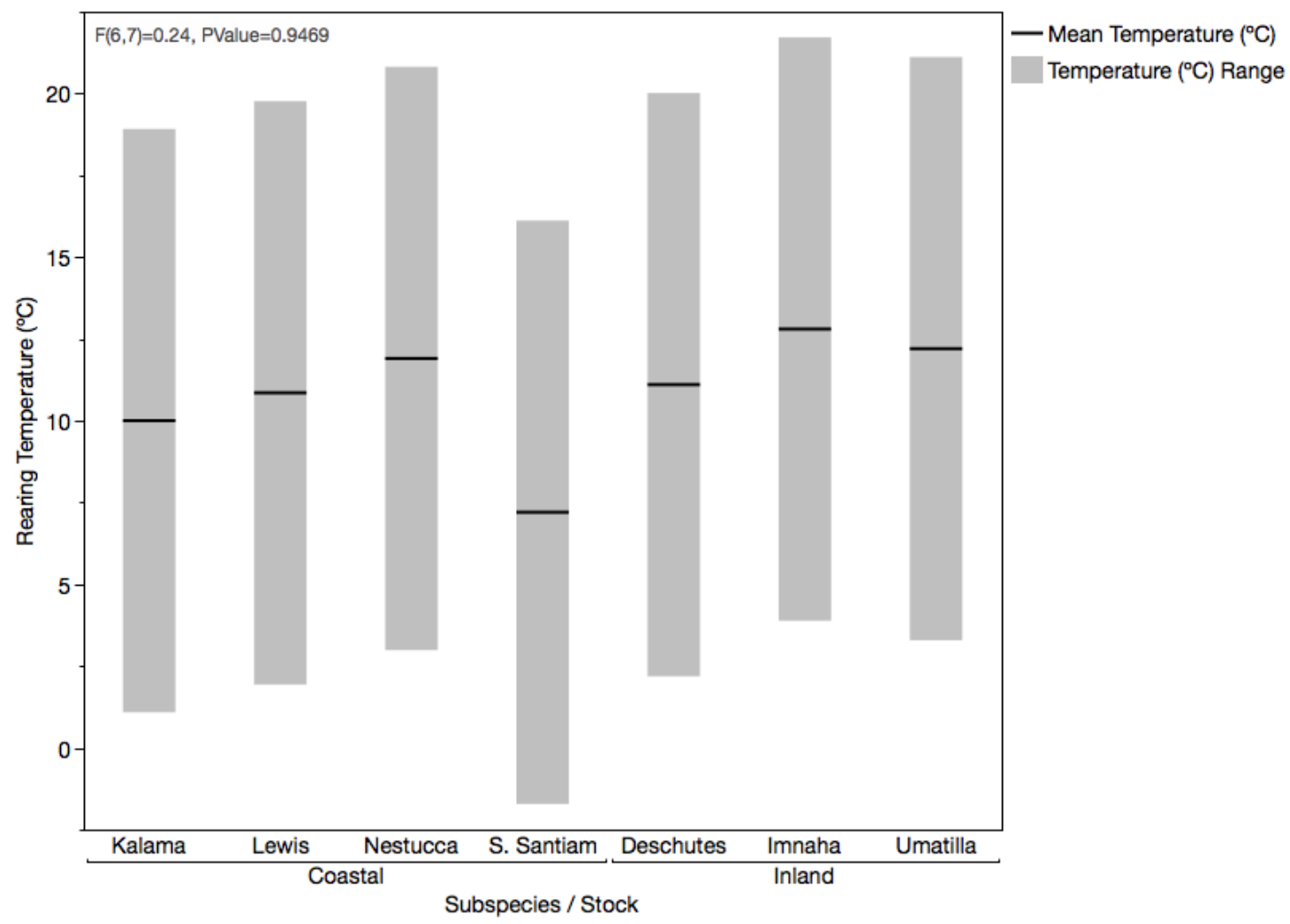

Figure $\mathrm{C} 2$. Comparison of hatchery rearing temperature $\left({ }^{\circ} \mathrm{C}\right)$ ranges by stock and subspecies, no paired t-test was significantly different between hatcheries. F-test shown for overall comparison in figure. 


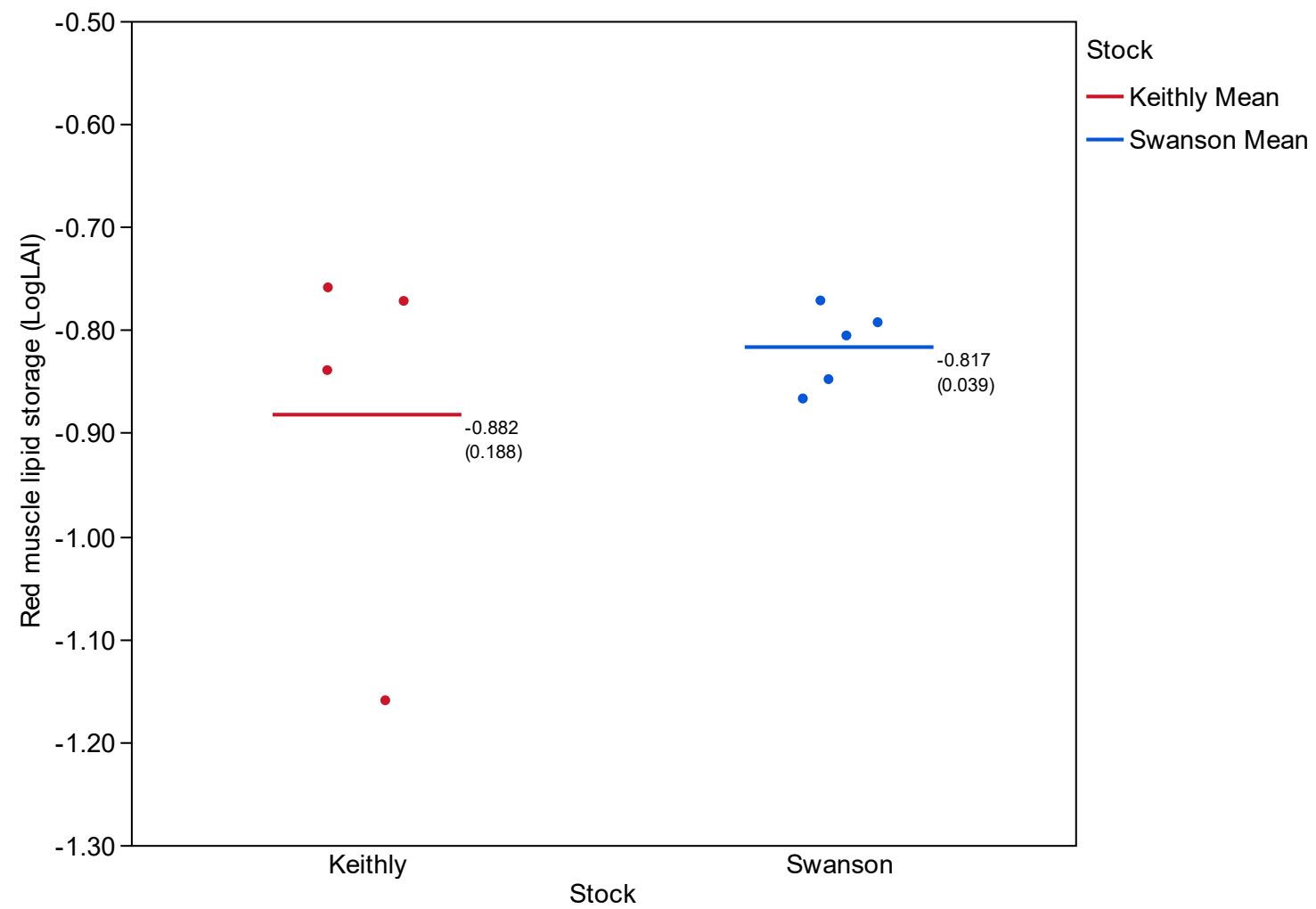

Figure C3. Comparison of red muscle lipid stores in clonal (YY male) O. mykiss by stock (inland Keithly $n=4$, and coastal Swanson $n=5$ ). Clonal lines were both reared under the same conditions by the Washington State University Center for Reproductive Biology. 